\title{
El Estado Autonómico tras la Ley de Garantía de la Unidad de Mercado y sus principios de necesidad y eficacia nacional
}

\author{
Manuel Rebollo Puig \\ Catedrático de Derecho Administrativo \\ Universidad de Córdoba ${ }^{(*)}$
}

SUMARIO: I. CONSIDERACIONES GENERALES SOBRE LA LEY DE GARANTÍA DE LA UNIDAD DE MERCADO 1. La premisa justificadora de la Ley: la fragmentación del mercado español. 2. Inspiración en la Directiva de Servicios y originalidad. 3. Unidad de mercado, desregulación y libertades económicas. 4. La inseguridad y conflictividad generadas. 5. La Ley no atribuye nuevas competencias al Estado. 6. La Ley impone límites a las Administraciones y también al legislador, en especial, al legislador autonómico, como ley básica. 7. La Ley limita la sujeción a controles administrativos previos pero también la imposición de condiciones materiales. 8. La LGUM, las autorizaciones y las alternativas ante su impuesto repliegue. II. LOS PRINCIPIOS DE NEGESIDAD Y PROPORGIONALIDAD DE LAS RESTRIGCIONES A LAS ACTIVIDADES ECONÓMICAS. 1. El nuevo significado del principio de necesidad: la transformación de las razones imperiosas de interés general y la configuración de la libertad de empresa. 2. La proyección del principio de necesidad sobre los controles administrativos previos. 3. El principio de proporcionalidad y el grado de restricción a las libertades económicas. 4. Necesidad, proporcionalidad y principio de precaución. 5. El significado de cada una de las razones imperiosas; en particular, el orden público y las invocaciones al orden público en la legislación andaluza. III. EL PRINCIPIO DE EFICACIA EN TODO EL TERRITORIO NACIONAL. 1. Eficacia nacional de normas y de controles previos de las autoridades infraestatales. Determinación de las autoridades de origen y de destino. 2. Eficacia nacional de las normas. 3. Eficacia nacional de los actos de control previo. 4. Efectos del principio de eficacia nacional; en particular, efectos sobre las competencias normativas autonómicas y peligro de la nivelación a la baja. 5. La correlativa distribución de las competencias de supervisión entre las autoridades de origen y de destino; el desarme de las autoridades de destino. 6. Juicio de constitucionalidad.

(*) Grupo de Investigación de la Junta de Andalucía SEJ-196. Proyecto de Investigación del Estado DER-2012/3569. 
RESUMEN: Se cuestiona la premisa de la que parte la Ley de Garantía de la Unidad de Mercado, así como sus soluciones. En concreto, de su principios de necesidad y proporcionalidad se afirma que consagran una concepción extrema de las libertades económicas y unas restricciones no justificadas a las competencias autonómicas. En cuanto al principio de eficacia nacional, tras analizar su significado y consecuencias directas e indirectas, se ponen de manifiesto sus peligros y sus demoledores efectos para la efectividad de las competencias autonómicas. Todo hasta concluir que la Ley supone una mutación constitucional.

ABSTRAC: In this paper, both the premise and the solutions envisaged by the Ley de Garantía de la Unidad de Mercado (Spanish Act on Market Unity). In concrete, its principles of necessity and proportionality are thought to consecrate an extreme conception of economic freedoms, as well as some unjustified restrictions to the autonomic competences. Regarding the principle of national efficacy, an analysis of its meaning and direct and indirect consequences is followed in this study by an assessment of its dangers and devastating effects for the effectiveness of the autonomic competences. This leads to the conclusion that the law implies a constitutional mutation.

PALABRAS CLAVE: Estado autonómico. Unidad de mercado. Proporcionalidad. Eficacia nacional y extraterritorialidad

KEY WORDS: Autonomous State. Unit of market. Proportionality. National efficiency and extraterritoriality

\section{GONSIDERACIONES GENERALES SOBRE LA LEY DE GA- RANTÍA DE LA UNIDAD DE MERGADO}

La Ley de Garantía de la Unidad de Mercado (LGUM) es una ley original, intrépida e ingeniosa. No se le pueden negar esas características. Distinto es si esas características son virtudes o defectos. También es una ley coherente en todas sus determinaciones y congruente con sus postulados y con su finalidad. Otra cosa es si esa finalidad es verdadera y predominantemente la de la garantizar la unidad del mercado nacional, como indica su denominación, si es ella la que le da coherencia o si tiene otros fines que la orientan al menos con el mismo vigor. De ello nos iremos ocupando al analizar concretamente sus dos pilares fundamentales: su consagración de un peculiar principio de necesidad y su proclamación de un drástico principio de eficacia nacional. Pero antes conviene exponer algunos aspectos generales. 


\section{La premisa justificadora de la Ley: la fragmentación del mercado español}

Afirma la Exposición de Motivos de la LGUM que "pese a las medidas adoptadas, la fragmentación subsiste en el mercado español". O sea, no ya que esté en peligro la unidad del mercado nacional, sino que se ha roto o, al menos, que no se ha logrado en la medida necesaria o apropiada. Y es eso lo que justifica y legitima esta Ley.

Es dura y osada esta afirmación sobre la fragmentación del mercado español que descalifica lo construido tras treinta y cinco años de Estado autonómico, con leyes estatales sobre los más diversos sectores y de jurisprudencia constitucional que, según ese juicio, no habrían evitado una situación claramente contraria a la querida por la propia Constitución.

Es, además, discutible. Hay quien la niega ${ }^{1}$. Por lo menos es difícil de asumir o rebatir en términos absolutos. Depende de lo que se entienda por unidad de mercado y por fragmentación del mercado. Pero, por lo menos, cabe seriamente ponerla en cuestión y afirmar, por el contrario, que se había logrado un equilibrio razonable y casi pacífico entre la autonomía y la unidad de mercado. Incluso cabe apostillar que tras la Directiva de Servicios y sus transposiciones, a veces exageradas, al Derecho español la unidad de mercado se había reforzado. En suma, no es aventurado afirmar que antes de la LGUM ya había un mercado nacional en el que las libertades de circulación encontraban pocas o livianas dificultades y en el que, por los mecanismos del Derecho interno o por los del Derecho europeo, se podían superar las distorsiones que se detectaran con los instrumentos ordinarios y bien consolidados y aceptados.

Si se duda de esta premisa de la LGUM se resquebraja la justificación de la propia Ley. Incluso si no se descartan por completo algunas disfunciones en algunos sectores y ciertas dificultades para la plena unidad de mercado y para la efectividad completa de las libertades de circulación de operadores económicos, de mercancías y de servicios, cabría imputar a la LGUM desmesura o desproporción si se pensara que ha acogido soluciones más restrictivas de la autonomía de las realmente necesarias para solventar aquellas disfunciones y dificultades.

${ }^{1}$ Así, por ejemplo, S. MUÑOZ MACHADO, "Sobre el restablecimiento legal de la unidad de mercado", REDA, no 163 (2014), sobre todo pp. 11 y 16, que califica esa afirmación sobre la fragmentación del mercado de "políticamente interesada" y "exagerada", lo que correlativamente le lleva a afirmar que la LGUM es de "dudosa necesidad y utilidad". 
Dejemos sólo apuntadas estas posibles objeciones basadas en las que, de entrada, suscita la premisa en la que se asienta la LGUM: la supuesta fragmentación del mercado español.

\section{Inspiración en la Directiva de Servicios y originalidad}

La LGUM tiene, no sólo su precedente, sino su musa y clara inspiración en la Directiva de Servicios, confesada en su misma Exposición de Motivos.

Desde luego, no es ni se muestra como una norma que pretenda continuar la transposición de tal Directiva.

Por lo pronto, desborda ampliamente el ámbito material de la Directiva de Servicios porque incluye a todas las "actividades económicas en condiciones de mercado" (art. 2); por tanto, también a las de elaboración y comercialización de productos $^{2}$. Ya no es sólo realización de la libre circulación de servicios sino también, como poco, de la de mercancías. Y con respecto a los servicios es de mayor amplitud: sólo quedan fuera las actividades que, en virtud del art. 128.2 CE, estén reservadas al sector público; si acaso cabe dudar de la sujeción de las actividades de servicio público no monopolizadas pues, pese a que respetan la iniciativa privada, no concurren con ella en condiciones de mercado; pero, en cualquier caso, las demás, incluso aunque puedan ser consideradas servicios de interés económico general si se ejercen en condiciones de mercado, quedan afectadas ${ }^{3}$.

2 Vid. G. FERNÁNDEZ FARRERES, "Unidad de mercado y libertades de empresa y circulación en le Ley 20/2013, de 9 de diciembre", REDA, nº 163 (2014), pp. 125-126.

${ }^{3}$ En cualquier caso, en lo estrictamente económico detiene su regulación y potencialidad nuestra Ley. Quiere decirse que no contribuye a la unidad de España o a la libre circulación de personas más allá de las actividades económicas y no afecta a todas las demás, por ejemplo, las de caza, que han sido muchas veces citadas para poner de manifiesto la necesidad de varios controles administrativos de diferentes Comunidades Autónomas para comprobar lo mismo y hacer lo mismo, aunque respecto a distintos territorios. Cuestión diversas es que las mismas ideas de la LGUM también se estén plasmando en esos otros ámbitos por otras leyes. Ejemplo revelador es el de la "licencia deportiva única" instaurada por el art. 23 de la Ley 15/2014, de 16 de septiembre, de racionalización del sector público y otras medidas de reforma administrativa, licencia que otorgarán las federaciones autonómicas pero que "producirá efectos en los ámbitos estatal y autonómico". Explica el preámbulo de tal ley que "esta medida contribuirá decisivamente a la extensión del principio de unidad de mercado en el ámbito del deporte no profesional, ya que permitirá eliminar duplicidades y reducir los trámites administrativos necesarios para la práctica del deporte”. Puede verse aquí otra aplicación del principio de eficacia nacional de los actos de entidades infraestatales similar a las que consagra la LGUM pero para un ámbito no afectado por ésta pues, aunque también aquí se hable de "unidad de mercado", en la medida en que se refiere al deporte no profesional, no estamos ante una actividad económica y sobrepasa el ámbito de la LGUM. 
Además, como iremos comprobando, sus soluciones son más radicales que las de la Directiva de Servicios, a veces más próximas, si acaso, a la propuesta inicial del Comisario Bolkestein que luego fue moderándose ${ }^{4}$.

Pero reconocidas todas esas importantes diferencias, es indudable su inspiración en la Directiva de Servicios donde encuentran precedente los términos que emplea, sus principios y parte de sus concreciones. Y sobre todo su táctica de garantizar la unidad de mercado y la libre circulación mediante la desregulación que se impone, al menos, a las Comunidades Autónomas y a los entes locales.

Con todo, la inspiración de la que hablamos es sólo eso y no está reñida con la originalidad de la LGUM que, con sutil y exquisita habilidad, cambia el significado y la función de los términos y principios de la Directiva de Servicios hasta construir algo distinto y novedoso. Alguna vez se ha dicho que no hay nada más original que nutrirse de los demás y que hasta el león está hecho de cordero asimilado. Pues siendo así, puede y debe reconocerse que la LGUM es verdaderamente original.

\section{Unidad del mercado, desregulación y libertades econó- micas}

Uniendo las ideas ya apuntadas, hasta podría sospecharse que la LGUM tiene por verdadero fin lo que presenta como un medio. Es decir, que más que preservar o potenciar la unidad del mercado nacional mediante la desregulación busca la desregulación misma. O que quiere la desregulación más allá de lo que la requiere la unidad de mercado. O, incluso, que más que la libre circulación persigue y consigue instaurar una concepción radical de las libertades económicas. Algo de esto indudablemente hay en la LGUM. Calibrarlo con exactitud exige analizar más concretamente su contenido. Pero digamos por ahora que la Exposición de Motivos da pistas en esa dirección. Ensalza los efectos negativos del "crecimiento de la regulación" (dificulta la competencia efectiva, impide aprovechar la economía de escala, desincentiva la inversión, reduce la productividad, el crecimiento y el empleo) y, con ese diagnóstico, lógico es que encuentre la medicina en la desregulación: “... esta Ley aprovecha para seguir impulsando un marco regulatorio eficiente para las actividades económicas, que simplifique la regulación existente, elimine regulaciones innecesa-

\footnotetext{
${ }^{4}$ Observa estas diferencias hasta afirmas que la "Ley estatal es mucho más liberalizadora" que la Directiva de Servicios, J. TORNOS MAS, "La Ley 20/2013, de Garantía de la Unidad de Mercado: una reforma discutible", en http//idepbarcelona.blogspot.com.es.
} 
rias...". Y tanto lo "aprovecha" que se puede tener la impresión de que es eso lo que prioritariamente pretende. Pero si fuese cierto e incluso sin cuestionar su constitucionalidad, entonces habría que decir que la Ley no es para la garantía de la unidad de mercado sino para la garantía de las libertades económicas. Y si así se aceptara, tal vez se comprenda mejor el juicio descalificador de la Exposición de Motivos, o sea, que lo que en el fondo quiere imputar al mercado español no es tanto que esté fragmentado como que está excesivamente regulado y constriñe más de lo conveniente las libertades económicas.

\section{La inseguridad y conflictividad generadas}

Todo ello, además, con una Ley que, sin que esto suponga un juicio peyorativo, es compleja y de la que es difícil determinar con certeza cuáles serán todas sus consecuencias sobre cada una de las regulaciones y sectores económicos, más todavía de lo que fue y sigue siéndolo la misma Directiva de Servicios en la que se inspira y a la que supera en amplitud y radicalidad. Y con una Ley que ha generado resistencia y conflictividad allá donde las cosas parecían más calmadas y en un momento poco oportuno.

En concreto, se han interpuesto contra la LGUM cuatro recursos de inconstitucionalidad: Primero, el promovido por el Parlamento de Cataluña $n^{\circ}$ 1397-2014, contra los arts. 14.2 y, por conexión, $23.2 ; 16 ; 17 ; 18$ y, por conexión, 5 y disposición final $2^{\text {a }}$; 19; 20; 26.5; 27 en relación con la disposición final $1^{\text {a }}$.3; disposición final $3^{\mathrm{a}} .1$ y por conexión 2 y disposición final $4^{\mathrm{a}}$. Segundo, el del Gobierno de Cataluña $\mathrm{n}^{\circ} 1411-2014$, contra los arts. $5 ; 6 ; 14.2 ; 16 ; 17 ; 18 ; 19 ; 20 ; 23 ; 26.5 ; 27$; disposición adicional $10^{\mathrm{a}}$; y disposiciones finales $1^{\mathrm{a}}, 2^{\mathrm{a}}, 3^{\mathrm{a}}$ y $4^{\mathrm{a}}$. Tercero, el interpuesto por el Consejo de Gobierno de la Junta de Andalucía n ${ }^{\circ}$ 1454-2014 contra los arts. $6 ; 14.2 ; 17$, último inciso del párrafo primero y letras a) a d); 18.2, letras b) a f); 19 ; $20 ; 21.2$ y $3 ; 23.2 ; 26 ; 27$; disposición adicional $10^{\mathrm{a}}$; y disposiciones finales $1^{\mathrm{a}}, 2^{\mathrm{a}} \mathrm{y}$ $4^{\mathrm{a}}$. Y cuarto, el promovido por el Gobierno de Canarias n ${ }^{\circ}$ 5437-2014, contra los arts. 6, 19 y 20. En conjunto, casi todo en lo que la LGUM tiene novedades relevantes está sometido al TC.

Por otra parte, de acuerdo con el art. 33 LOTC, se han realizado negociaciones en el seno de las correspondientes Comisiones Bilaterales de Cooperación entre la Administración General del Estado y la correspondiente Comunidad Autónoma para resolver discrepancias sobre la LGUM. También esto revela la conflictividad que ha generado y, sobre todo, las dudas y la inseguridad que ha suscitado y suscita su contenido. En concreto, tales negociaciones se entablaron exitosamente con el País Vasco y con Galicia. En el caso del País Vasco se iniciaron sin señalar los preceptos objeto de discrepancia (BOE de 1 de abril de 2014), pero lográndose finalmente un 
Acuerdo en la Comisión Bilateral (publicado en BOE de 12 de agosto) en el que "ambas partes consideran solventadas" las discrepancias "en razón a las siguientes consideraciones...". En cuanto a Galicia las discrepancias se producían respecto de los arts. $3.1 ; 5 ; 6 ; 7 ; 16 ; 17 ; 18 ; 19 ; 20 ; 21.2 ; 26 ; 27.1$ y $6 ; 28$; disposiciones adicionales $4^{\mathrm{a}}$ y $10^{\mathrm{a}}$; y disposiciones finales $1^{\mathrm{a}}, 2^{\mathrm{a}}, 3^{\mathrm{a}}$ y $4^{\mathrm{a}}$ (BOE de 4 de abril de 2014); y se llegó a un Acuerdo (BOE de 29 de octubre) sobre las discrepancias por el que "ambas partes las consideran solventadas de conformidad con los siguientes compromisos...". También con Canarias se acudió a este cauce (BOE de 1 de abril de 2014) respecto a los arts. 6, 19 y 20, pero no se llegó a acuerdo y, como se ha visto, el Gobierno canario ha interpuesto recurso de inconstitucionalidad contra esos mismos artículos.

Los Acuerdos con el País Vasco y con Galicia están plagados de expresiones como "ambas partes coinciden en interpretar que...", tal precepto "se interpretará en el sentido de que...", "se entenderá en el sentido de que...". Pero su valor jurídico es reducido y, desde luego, no vinculan a terceros ni a los tribunales ordinarios ni al Constitucional, aunque quizás consigan orientar su interpretación.

En cualquier caso, sirven también estos Acuerdo para poner de relieve que no es nada fácil desentrañar el verdadero significado y alcance de la LGUM y su fuerza transformadora y que genera una inseguridad jurídica que afectará a los distintos poderes y a los ciudadanos y empresas, y que no es arriesgado augurar que dará lugar a una litigiosidad que no siempre se canalizará por los cauces ad hoc previstos por la misma LGUM. Inseguridad y litigiosidad, cabe añadir, en la que quizás las empresas vean más inconvenientes que en las livianas limitaciones a la libre circulación que supuestamente sufrían.

\section{La Ley no atribuye nuevas competencias al Estado}

La Ley no otorga nuevas competencias al Estado. En ese sentido puede decirse, como se ha dicho, que no recentraliza. Claro está que en la aprobación misma de la Ley hay ejercicio de competencias estatales (las invocadas en la disposición final $4^{\mathrm{a}}$ de la LGUM) y un ejercicio de amplitud y alcance cuestionables. Pero en ella no se atribuye ninguna nueva competencia al Estado, ni normativa ni ejecutiva. Paralelamente puede decirse que no priva a las Comunidades Autónomas ni a los entes locales de ninguna de sus competencias. Aun reconociéndolo así, sí que se afecta a las competencias de los entes infraestatales. De dos formas: les impone nuevos límites de respeto a una ley estatal; y delimita entre sí las competencias de los distintos entes territoriales, sobre todo de las diversas Comunidades Autónomas entre sí. Y, como iremos viendo, todo ello hasta conformar un entramado que encorseta notablemente el ejercicio y la efectividad de las competencias autonómicas. 


\section{La Ley impone límites a las Administraciones y también al legislador, en especial, al legislador autonómico, como ley básica}

Los mandatos y prohibiciones de la LGUM están dirigidos formalmente en la mayoría de los casos a "las autoridades competentes". Esa expresión lleva a pensar sobre todo en autoridades administrativas. Por tanto, cabe creer que la LGUM supone restricciones a las distintas Administraciones públicas. Es más, muchos de sus preceptos sólo pueden tener como destinatarias a éstas y a sus autoridades y órganos. Inclinan en igual dirección los mecanismos instaurados por la Ley para su efectividad pues, al encaminarse finalmente hacia la jurisdicción contencioso-administrativa, hacen pensar que lo susceptible de impugnación y lo que es aquí objeto de disciplina son sólo las actividades administrativas. Lo anterior hay desde luego que completarlo respecto a los Colegios Profesionales y toda la organización colegial, y, por otra parte, respecto a los organismos privados de normalización y de acreditación que, en su caso, también podrían quedar vinculados por la LGUM.

Pero hay más que eso y es lo que importa realzar: hay también indudablemente mandatos y prohibiciones a las leyes, a los legisladores. Se deduce de que sus restricciones a las "disposiciones de carácter general" o simplemente a las "normas" (arts. $3.1,9.2,15$, etc) se consagran sin calificar nunca a éstas como administrativas o de rango inferior a la ley. Se deduce asimismo de que en que en algún caso se habla expresamente de leyes (así, art. 14.3 y 6). Se confirma al comprobar que se dirige reiteradamente a cualquier autoridad, no sólo a las administrativas. Es más, cuando define en su anexo "autoridad competente", se refiere al final "en particular" a las administrativas y colegiales, pero tras partir de un concepto mucho más amplio en el que entra cualquiera que "lleve a cabo la regulación, ordenación ... de las actividades económicas o cuya actuación afecte al acceso a una actividad económica o a su ejercicio", y ello incluye de modo inequívoco a los distintos legisladores. Pero sobre todo se deduce de su mismo propósito y contenido: si se trata de asegurar la unidad del mercado nacional ello hay que garantizarlo por igual frente a las actuaciones administrativas y frente a las normas con rango de ley. Desde ese punto de vista, igual que sucede con la unidad del mercado europeo, es irrelevante qué poder público ice el obstáculo. Y todo el propósito de la Ley quedaría arruinado si no fuese así y si bastara a una Comunidad Autónoma aprobar una norma con rango de ley para quedar al margen de los principios de necesidad, de proporcionalidad y de eficacia nacional tal y como son configurados en la LGUM y para, con sólo eso, no encontrar más condicionantes que los derivados directamente de la Constitución. En suma, pues, las restricciones de la LGUM son restricciones a todos los poderes públicos, incluidos los legisladores.

Sucede, sin embargo, que, a la postre, los que especialmente sufren tales restricciones son los legisladores autonómicos. Demostrémoslo. 
Por lo pronto, es claro que las normas internacionales y sobre todo las de la Unión Europea quedan por completo al margen. Además de que no puede ser de otra forma, la misma LGUM lo reconoce en algún caso [arts. 16, 17.1.d)].

Por otra parte, lo pretenda o no la LGUM y aunque se exprese como si obligara a todas las autoridades nacionales, tampoco el legislador estatal queda sujeto a las restricciones regulatorias que esta Ley impone. Si acaso, algunos de sus mecanismos, como el de la evaluación periódica de la normativa (art. 15), pueden afectarle. Pero las leyes del Estado, dentro de sus competencias, podrán seguir imponiendo límites a las libertades económicas sin encontrar freno efectivo en la LGUM; lo tendrán, eso sí, en la Constitución, en particular, en su art. 139 CE, en el Derecho de la Unión Europea y en la unidad de mercado tal y como está consagrada en aquélla y en éste, pero no en las concreciones y adiciones de la LGUM. Los esfuerzos doctrinales por imponer que las leyes básicas hayan de ser respetadas por el propio legislador esta$\mathrm{tal}^{5}$ no han encontrado el respaldo del $\mathrm{TC}^{6}$ y realmente son difíciles de construir y articular. Sobre todo no quedarían vinculadas las otras leyes básicas. Así que, en suma, las leyes estatales podrán seguir estableciendo límites materiales y formales a las actividades económicas (p. ej., autorizaciones) que no se acomoden a las previsiones de la LGUM.

Por el contrario, el carácter íntegramente básico de esta Ley (disposición final 4ª), hace que las leyes autonómicas sí que queden estricta y plenamente constreñidas por todas y cada una de sus determinaciones.

Naturalmente, lo mismo y con más razón puede decirse de los entes locales y, en especial de sus ordenanzas. Sin embargo, la relevancia que a este respecto se confiera a la LGUM depende en realidad de lo que se considere que es la situación de partida de los entes locales, o sea, la que tenían antes de la LGUM o la que tendrían aunque ésta no se hubiera aprobado o se derogase o anulase íntegramente. Si se parte de

${ }^{5}$ Vid. J. M. BAÑO LEÓN, "La vinculación del Estado a las normas básicas de contratación: la prohibición de derogación singular de las bases", en R. GÓMEZ-FERRER MORANT (Dir.), Comentarios a la Ley de Contratos de las Administraciones Públicas, Civitas, Madrid, 2a ed., 2004, pp. 1753 y ss.; y G. FERNÁNDEZ FARRERES, La contribución del Tribunal Constitucional al Estado autonómico, Iustel, Madrid, 2005, pp. 312 a 315.

Además, han defendido que las bases vinculan al propio Estado, F. LÓPEZ MENUDO, "Títulos hábiles para la utilización de los bienes y los derechos demaniales. Tipología y régimen”, en C. HORGUÉ BAENA, Régimen patrimonial de las Administraciones públicas, Iustel, Madrid, 2007, pp. 200-201; y M. LÓPEZ BENÍTEZ, "Las normas básicas y las competencias estatales del artículo 149.1.18 de la Constitución”, en Régimen jurídico básico de las Administraciones públicas. Libro homenaje al Profesor Luis Cosculluela, Iustel, Madrid, 2015, p. 114.

${ }^{6}$ Es particularmente significativa la STC 240/2006, de 20 de julio que no parece admitir que las leyes básicas -en el caso, la Ley Reguladora de las Bases del Régimen Local- sean canon de constitucionalidad de las leyes estatales. 
un concepto radical de autonomía local y de un poder de ordenanza extenso que pueda establecer límites a las actividades privadas -incluidas las de ejercicio de las libertades económicas- con pocos frenos, incluso en materias reservadas a la ley, entonces habrá que entender que la LGUM supone una notable restricción. Sostengo, por el contrario, que, aunque la autonomía local matiza el principio de vinculación positiva a la ley y que sus ordenanzas no tienen una posición ordinamental asimilable a los reglamentos ejecutivos, no pueden, incluso al margen de la LGUM, introducir límites a la libertad de empresa y de profesión nada más que con específico fundamento legal, salvo, si acaso, por razones de orden público ${ }^{7}$. No es cuestión de entrar aquí en ese debate. Digamos sólo que si se acepta esta última tesis la repercusión de la LGUM sobre los entes locales es menor y, en cualquier caso, más fácil de acomodar a la Constitución. Tendríamos, en suma, que a quienes realmente constriñe la LGUM es a los legisladores autonómicos; si acaso, también a los legisladores autonómicos cuando atribuyan potestades y competencias a los entes locales para ordenar y limitar las actividades económicas privadas.

\section{La Ley limita la sujeción a controles administrativos pre- vios pero también la imposición de condiciones materiales}

$\mathrm{Al}$ igual que la Directiva de Servicios y las normas españolas que dictadas con su ocasión o pretexto, la LGUM restringe la posibilidad de someter las actividades privadas a controles administrativos previos, o sea, a autorizaciones y similares. Ahora más intensamente, además de que también hay algunas restricciones a la posibilidad de exigir comunicaciones y declaraciones responsables, como se verá. Pero ello, en principio, nada tiene que ver con la posibilidad de imponer restricciones materiales a esas actividades privadas: se permitiría, por ejemplo, imponer deberes, prohibiciones y limitaciones de todo género a la actividad de campamentos o de agencias de viaje, aunque no se pudiera controlar previamente la observancia de todo eso mediante una autorización o similar. Si esto fuese todo, cabría pensar que no hay merma sustancial para la configuración por los poderes públicos de las libertades económicas en función de lo que entiendan conveniente para los intereses generales que detecten y quieran preservar: para la defensa de cualquiera de ellos cabría imponer las restricciones a las actividades privadas que los poderes públicos juzguen oportunas con la sola condición de no controlarlas mediante autorizaciones. Sólo obligaría, por tanto, a un cambio de estrategia en el control administrativo que perdería el arma de la autorización. Pero ello ni siquiera habría de entrañar una "desadministra-

7 Vid. M. REBOLLO PUIG y M. IZQUIERDO CARRASGO, “Artículo 84”, en M. REBOLLO PUIG (Dir.) y M. IZQUIERDO CARRASCO (Coord.), Comentarios a la Ley Reguladora de las Bases del Régimen Local, Tirant lo Blanch, Valencia, 2007, II, pp. 2189 a 2196. 
tivización" pues la inexistencia de una autorización no niega la posible existencia de todo tipo de restricciones materiales ni de otras potestades administrativas para su control y para reaccionar ante su transgresión, como luego razonaremos.

Pero, en realidad, la unidad de mercado -o simplemente la libertad de empresasiempre ha supuesto algo más, siempre ha significado restricciones a los poderes públicos para imponer prohibiciones y limitaciones materiales a las actividades privadas concernidas. Es más, eso era lo esencial, y las limitaciones a la sujeción a autorizaciones eran más bien una consecuencia o complemento adicional. En la misma Directiva de Servicios y en las normas españolas de trasposición esa otra vertiente esencial de la unidad de mercado también ocupaba un papel central pese a que en España se enfatizó sobre todo su repercusión sobre las autorizaciones. Ahora, con la LGUM, esta otra vertiente se potencia notablemente. La libertad que se proclama no es sólo ni fundamentalmente libertad frente a autorizaciones y controles administrativos previos; los límites a las actividades privadas que se proscriben o reducen no son los meramente formales o burocráticos, sino también los materiales ${ }^{8}$. Y es éste, además, el aspecto más importante, el capital, el de más calado, el que restringe más sustancial y severamente las competencias de los distintos poderes públicos y el que, quizás, debilita más sus posibilidades de tutelar aquéllos que consideren intereses generales.

\section{La LGUM, las autorizaciones y las alternativas ante su impuesto repliegue}

Como acabamos de decir, en la LGUM, al igual que en toda la normativa que arranca de la Directiva de Servicios, se restringe notablemente la posibilidad de someter las actividades privadas a la obtención de autorizaciones. Pero conviene completar ese aspecto señalando que, además, también se afecta al régimen de las autorizaciones que puedan subsistir: se potencia su carácter reglado, se trata de reducir las cargas formales que entraña, se acentúa su eficacia temporal indefinida, se refuerza el silencio positivo, se reduce la posibilidad de limitar su número... A este respecto la LGUM sólo da algunos nuevos pasos. El más destacable y acertado es el de proclamar más claramente que sólo por norma con rango de ley puede sujetarse una actividad económica a este medio de control administrativo previo. Por otra parte, su

${ }^{8}$ Lo destaca certeramente M. RODRÍGUEZ PORTUGUÉS, "El impacto de la Ley de Garantía de la Unidad de Mercado sobre la ordenación del comercio interior", en M. J. ALONSO MAS (Dir.), El nuevo marco jurídico de la unidad de mercado. Comentario a la Ley de Garantía de la Unidad de Mercado, La Ley, Madrid, 2014, pp. 543-544. 
consagración del "principio de simplificación de cargas" (art. 7) podrá servir para aligerar la documentación exigida al solicitante y los trámites del procedimiento autorizatorio.

Pero, al margen de ello, lo que luce más destacadamente en la LGUM es una nueva restricción a las posibilidades de imponer autorizaciones. Sus dos grandes principios, que ahora analizaremos, conducen a ello inexorablemente. Sin cuestionar las ventajas que ello entraña, ofrece un panorama diferente con nuevos problemas que el legislador español debería abordar sin que hasta ahora lo haya hecho suficiente y satisfactoriamente. Esto es especialmente necesario si se tiene en cuenta que muchos sectores de nuestro ordenamiento eran, si se me permite la expresión, "autorizocéntricos" de modo que depositaban en la autorización mucho más peso que el de ser un medio de vigilancia previa. Así, la desaparición de autorizaciones deja vacíos que hay que colmar para que lo que es sólo la reducción de una técnica de control previo no suponga un daño para los intereses generales en juego ni para la seguridad jurídica ni deje inerme a la Administración para su defensa ni a los terceros eventuales perjudicados por actividades privadas ilegales ${ }^{9}$.

La LGUM, aunque profundiza decididamente en esa erosión de las autorizaciones, poco aporta en la construcción de alternativas. Apenas sus preceptos sobre colaboración entre las distintas Administraciones (arts. 22 a 25) que, aunque valiosos en sí mismos, son por completo insuficientes para llenar el vacío que deja la desaparición de autorizaciones. Y tal vacío tampoco lo cubren, desde luego, las comunicaciones y las declaraciones responsables porque ninguno de esos actos del administrado inicia un procedimiento ni obliga a inspeccionar ni origina necesariamente una resolución administrativa ni, por ende, silencio administrativo; tampoco ofrecen un título habilitante que dé seguridad al titular de la actividad ni dan cabida a la intervención de terceros... Cosa distinta es que, dada la relevancia que están adquiriendo las comunicaciones y las declaraciones responsables, sí que merezcan una regulación general más completa y atinada que la que del art. 71 bis LRJAP introducida en 2009. No era misión de la LGUM afrontar esa regulación de las alternativas a las autorizaciones ni ésta habría encontrado aquí su lugar adecuado. Pero sí es seguro que

${ }^{9}$ Vid. J. M. BAÑO LEÓN, "Declaración responsable y derechos de terceros. El lado oscuro de la llamada Better regulation", trabajo para el libro homenaje al Prof. Cosculluela Montaner y publicado también en REDA n 167 (2014), pp. 23 a 44; y M. REBOLLO PUIG, "El repliegue de las autorizaciones y la articulación de alternativas. En especial, la tutela de los terceros perjudicados por actividades privadas ilegales", en J. E. SORIANO GARCíA (Dir.) y M. ESTEPA MONTERO (Coord.), Por el Derecho y la libertad. Libro homenaje al Profesor fuan Alfonso Santamaría Pastor, Iustel, 2014, II, pp. 1991 a 2017. 
la LGUM hace aun más perentoria esa tarea para que la desaparición de tantas autorizaciones no merme la capacidad de control y de reacción frente a las actividades privadas ilegales. La nueva ley de Procedimiento Administrativo que ahora se tramite es la oportunidad perfecta para abordar seriamente esa tarea.

\section{LOS PRINGIPIOS DE NEGESIDAD Y PROPORGIONALI- DAD DE LAS RESTRICGIONES A LAS ACTIVIDADES EGONÓMICAS}

\section{El nuevo significado del principio de necesidad: la trans- formación de las razones imperiosas de interés general y la configuración de la libertad de empresa}

El art. 5 LGUM contiene un precepto clave sobre el que tal vez no se haya reparado suficientemente. Comporta el límite más general y riguroso a los poderes públicos infraestatales de cuantos contiene esta Ley y, en realidad, una configuración radical de las libertades económicas (sobre todo la libertad de empresa pero también la de profesión y oficio). La libertad de empresa consiente, conforme al art. $38 \mathrm{CE}$, limitaciones basadas en muy diversas razones obedientes a diferentes intereses generales seleccionados y valorados con gran margen de apreciación por el legislador. Ese precepto se refiere en concreto a la "defensa de la productividad", a las "exigencias de la economía general" y a la planificación. En suma, admite restricciones basadas en cualquier valor constitucional, incluidos estos de carácter marcadamente económico. Lo mismo puede decirse de la libertad de profesión y oficio y, desde luego, de la propiedad pues la función social que la delimita (art. $33 \mathrm{CE}$ ) queda muy abierta a las valoraciones que las leyes hagan de los más distintos intereses generales.

Sin embargo, el art. 5.1 LGUM consagra como "principio de necesidad" que las leyes sólo podrán imponer límites a la libertad de empresa y de profesión por determinadas razones tasadas y por ninguna otra. Son las "razones imperiosas de interés general" enumeradas exhaustivamente el en el 3.11 de la Ley 17/2009 o "ley paraguas". O sea, que ese principio de necesidad no significa sin más que esas limitaciones hayan de ser necesarias para la defensa de cualquier interés general o para los que tengan respaldo constitucional, sino necesarias precisamente para la protección de unos cuantos intereses elegidos por el mismo legislador estatal; cualquier otro interés general queda proscrito como posible justificación de límites a las libertades económicas, como posible finalidad de las restricciones a esas libertades; y ello con independencia de que supongan o no trabas para la libre circulación o unidad de mercado.

Eso es lo que el art. 5.1 LGUM establece, aunque lo haga de forma alambicada y más obscura. Es así porque, aunque formalmente se exprese como una mandato de 
motivación ("Las autoridades ... motivarán..."), realmente contiene una prohibición de imponer límites por otros motivos; porque aunque se dirige a las "autoridades" afecta fundamentalmente al legislador que es quien puede establecer límites a las libertades económicas o habilitar a la Administración para imponerlos; porque entre los límites sometidos a tal necesidad no están sólo los relativos al acceso a la actividad ni sólo los formales (autorizaciones y similares) sino también los que afecten al ejercicio de la actividad y los que supongan cualquier límite material. Es más, si se refiriese sólo a la necesidad de autorizaciones, el art. 5.1 sobraría y estaría contradicho por el resto de la Ley que, en realidad, sólo permite la sujeción a autorizaciones por motivos aun más reducidos, no por todas las razones imperiosas de interés general, como se expondrá después.

La lista de las razones imperiosas de interés general es relativamente amplia. Las define así el art. 3.11 de la Ley 17/2009, al que se remite el art. 5 LGUM: <<"Razón imperiosa de interés general": razón definida e interpretada (por) la jurisprudencia del Tribunal de Justicia de las Comunidades Europeas, limitadas las siguientes: el orden público, la seguridad pública, la protección civil, la salud pública, la preservación del equilibrio financiero del régimen de seguridad social, la protección de los derechos, la seguridad y la salud de los consumidores, de los destinatarios de servicios y de los trabajadores, las exigencias de la buena fe en las transacciones comerciales, la lucha contra el fraude, la protección del medio ambiente y del entorno urbano, la sanidad animal, la propiedad intelectual e industrial, la conservación del patrimonio histórico y artístico nacional y los objetivos de la política social y cultural $>>$. Pero, aunque amplia, también es mucho lo que queda fuera de ella. Entre otras cosas, quedan fuera las razones expresamente admitidas por el art. 38 CE para limitar la libertad de empresa, o sea, la "defensa de la productividad" y las "exigencias de la economía general" y la planificación. Fuera quedan también razones ínsitas en los arts. 128 y 131 CE. Y otras muchas más concretas que quizá pudieran entenderse comprendidas en ellas o en otros preceptos constitucionales, desde la protección de los pequeños empresarios o de la artesanía o de las cooperativas, o la integración de los discapacitados o de personas en riesgo de exclusión social, etc. Incluso la protección de la infancia y adolescencia o la lucha contra la ludopatía quedan a expensas de cómo se interprete el orden público o la salud pública.

Con todo esto se han establecido unas restricciones a los poderes públicos que de ningún modo encuentran justificación en la Constitución ni en sus garantías de la unidad de mercado. También estas garantías incluyen, según el TC, un principio de necesidad o, para ser más exactos, un principio de proporcionalidad que, entre otras cosas, exige que las medidas sean necesarias para el logro de la finalidad perseguida. Pero las finalidades que lícitamente podían perseguirse no estaban tasadas. Menos todavía cabía identificarlas con las que el Tribunal de Luxemburgo había considerado a sus efectos razones imperiosas de interés general. 
Pero es que tampoco rige nada de esto en la Unión Europea que no impone a las autoridades nacionales semejantes restricciones a su regulación. Ni siquiera con la Directiva de Servicios llegó a tanto. La solución de la LGUM se sirve de algunos términos e ideas del Derecho europeo pero las transforma. No sólo ni fundamentalmente porque restrinja las razones imperiosas de interés general sino porque les atribuye una función que no tienen allí.

Por lo que se refiere al cambio del concepto de razón imperiosa de interés general baste decir que tales razones no están cerradas en el Derecho de la Unión, que pueden ser todas las que, como su nombre indica, sean realmente imperiosas para un interés general que se juzgue digno de protección y de suficiente valor como para permitir un obstáculo a la libertad de establecimiento y de prestación de servicios. Los Estados miembros son los primeros llamados a valorar esas circunstancias y, por tanto, a decidir si justifican límites a las actividades económicas y, en su caso, obstáculos a la libre circulación. Ocurre sólo que esas decisiones de las autoridades nacionales están sometidas al control del Tribunal de Justicia que decidirá caso por caso si el interés general invocado y efectivamente perseguido por el Estado miembro es, por así decirlo, de suficiente peso o importancia para justificar el obstáculo introducido a la libertad de establecimiento y de servicios. El Tribunal de Justicia nunca ha cerrado la puerta a nuevas razones imperiosas, si bien se guarda la llave. La Directiva de Servicios, aunque respetaba ese planteamiento, enumeró las principales razones imperiosas de interés general ya admitidas por la jurisprudencia comunitaria, pero lo hacía como una mera enunciación no agotadora y definitiva sino abierta y que, por tanto, admitía que hubiera otras que invocaran los Estados miembros y obtuvieran el plácet del Tribunal de Justicia. Al trasponerse en España, la ley paraguas en su transcrito art. 3.11, convirtió en una lista cerrada y exhaustiva lo que no lo es y ofreció como una foto fija y definitiva lo que de ninguna forma lo es para la Unión. Con ello ya conseguía una restricción a los poderes nacionales que no impone el Derecho europeo.

Pero lo más trascendental es que en el Derecho español, con la LGUM, se atribuye a las razones imperiosas de interés general una función mucho más relevante que la que le confiere el Derecho europeo incluso tras la Directiva de Servicios. Allí, por lo pronto, sólo son las que se pueden invocar para justificar obstáculos a la libertad de establecimiento y de servicios; si acaso, también a la libre circulación de capitales. Pero si lo que está en juego es la libre circulación de mercancías se utiliza otra expresión, la de "exigencias imperativas", que, aunque similar, no es idéntica y que el Tribunal de Justicia no intercambia. Con la LGUM, sobre todo con su art. 5.1, las razones imperiosas de interés general sustituyen a las "exigencias imperativas". Pero hay algo más; y algo más importante. En el Derecho de la Unión tanto las "razones imperiosas de interés general" como las "razones imperativas" son las que, partiendo de que los Estados miembros son competentes para imponer cualesquiera límites a las libertades económicas indistintamente aplicables a nacionales y extranjeros co- 
munitarios, pueden justificar que de hecho dificulten más la actividad de estos o la hagan menos atractiva o menos rentable que la de aquellos. Si no se producen esas dificultades, ningún inconveniente se pone a que los Estados miembros limiten las libertades económicas por cualquier fin. Incluso todavía hay que añadir que cuando sí entrañan esas diferencias que de hecho colocan al extranjero comunitario en peor situación para competir, tampoco por ello serán ilícitas sino sólo no oponibles a éste. Y ello, con alguna matización, sigue siendo así tras la Directiva de Servicios. Cierto que ésta ya aumentó algo las funciones de las razones imperiosas de interés general (simplificando algo, las convirtió en las únicas que justificaban autorizaciones y las reglas de la llamada "lista gris"), pero no fue más lejos. Por el contrario, el art. 5.1 LGUM, no sólo superando a la Directiva de Servicios sino a todas las normas españolas anteriores que más o menos acrobáticamente se fundamentaban en ella, convierte a las razones imperiosas de interés generales en las únicas que pueden justificar límites a las libertades económicas, aunque sean límites aplicables indistintamente a todos y aunque no comporten de derecho ni de hecho ninguna dificultad superior para los operadores foráneos.

Lo anterior demuestra que el llamado "principio de necesidad" del art. 5.1 LGUM lo que realmente intenta va más allá de la preservación de la unidad de mercado. Se desenvuelve y juega al margen de ella, con total independencia de lo que se supone es la finalidad de esta Ley. Pone límites, no sólo ni principal o directamente a los obstáculos a las libertades de circulación, sino a cualquier restricción a las libertades económicas. Es mucho más que un medio para asegurar la libre circulación de servicios y productos. Lo que realmente intenta es consagrar una configuración radical de la libertad de empresa que, con independencia de cualquier peligro para la unidad del mercado nacional y las libertades de circulación, restringe drásticamente las posibilidades del legislador para limitar su ejercicio ${ }^{10}$. Se evidencia aquí y alcanza su máxima potencia el propósito desregulador que luce en la Exposición de Motivos de la LGUM y que ya antes recordábamos. Más aún, su art. 5.1 es directa y preponderantemente desregulador mucho más allá de lo que reclama la unidad de mercado.

${ }^{10}$ Es esta idea la que defiendo más detenidamente en "La libertad de empresa tras la Ley de Garantía de la Unidad de Mercado", REDA, n' 163 (2014), pp. 23 a 33, y en la que coincido por completo con G. FERNÁNDEZ FARRERES, "Unidad de mercado y libertades de empresa y circulación...", publicado en la mismo no 163 de la REDA, y que en p. 124 afirma que en la LGUM "las consecuencias vinculadas a este principio de necesidad y proporcionalidad trascienden del objetivo de garantizar la unidad de mercado"; y que "resulta inapropiada, además de innecesaria, la apelación a la garantía de la unidad de mercado para tratar de justificar la opción política, de marcado signo liberalizador, por la que se ha decantado la LGUM". Porque "lo que se viene a reforzar es la libre iniciativa económica o, si se quiere, la libertad de empresa, pero no, al menos en estrictos términos, la unidad de mercado". 
Cuestión distinta es que, por los motivos que antes explicamos, este intento no puede alcanzar del todo sus objetivos porque esa concepción extrema de las libertades económicas que consagra de poco valdrá frente a las normas internacionales y sobre todo europeas y ni siquiera frente a las leyes estatales, que podrán seguir imponiendo límites a las libertades económicas por cualesquiera fines aunque no entren dentro de las razones imperiosas de interés general. Al cabo, sólo hay un recorte de las posibilidades de los legisladores autonómicos y, si acaso, con las dudas antes apuntadas, de los entes locales. Con esta salvedad, el art.5.1 LGUM es sólo fundamentalmente una garantía de la libertad de empresa y de profesión y oficio frente a las leyes de las Comunidades Autónomas que, aunque no ven reducidas sus competencias en favor del Estado, sí que las ven encorsetadas por un nuevo límite material: no restringir las libertades económicas nada más que por ciertas razones elegidas por el Estado.

Así las cosas, no es fácil justificar la adecuación de este art. 5.1 a la Constitución, máxime respecto a materias de la exclusiva competencia autonómica como agricultura, vivienda, comercio interior, turismo ... Si son exclusivas de las Comunidades Autónomas, ¿cómo justificar que sea el Estado quien decida las finalidades que puedan justificar cualquier límite a las libertades económicas en esos sectores? Cierto que las competencias transversales del Estado como las invocadas por la propia LGUM (arts. 149.1.1 ${ }^{\mathrm{a}}$ y $13^{\mathrm{a}}$ ) le permiten entrar incluso en las materia exclusivas, pero ello a condición de siquiera invocar una conveniencia de establecer un mínimo común uniforme que sólo es imaginable para cada sector y para cada regulación concreta, no para todos y para meramente impedir la regulación autonómica.

No es impertinente aclarar por último que lo que la LGUM, aunque ya con algún precedente reciente a partir de la Directiva de Servicios, presenta como principio de necesidad no es a lo que tradicionalmente se ha llamado así. La necesidad de que antes se hablaba era una parte del principio de proporcionalidad y sólo significaba que la medida adoptada, pese a ser restrictiva de alguna libertad o de la unidad de mercado, debía ser la menos limitativa de las adecuadas para conseguir la finalidad perseguida. Ahora lo veremos. Lo que en este momento importa subrayar es que la necesidad no comportaba ninguna delimitación de las finalidades lícitamente perseguibles sino que, partiendo de una finalidad lícita cualquiera, imponía que se tomara la menos limitativa, la más suave. Ahora, por el contrario, con el nombre de principio de necesidad se ha introducido algo por completo distinto: un acotamiento de las finalidades que puede perseguir incluso el legislador para limitar la libertad económica.

Así que, hablando de principio de necesidad y de razones imperiosas de interés general, todo suena parecido a lo que había antes, pero con las mismas palabras se ha construido un sistema por completo diferente. 


\section{La proyección del principio de necesidad sobre los con- troles administrativos previos}

Ni siquiera las razones imperiosas de interés general incluidas en la lista tasada y reinventada por el legislador español son suficientes para cualquier restricción. En concreto, no lo son para imponer el sometimiento a autorización. A este respecto, las razones justificativas son menos. Lo establece el art. 17.1 LGUM que no habla de razones imperiosas de interés general.

Admite siempre las autorizaciones cuando el número de operadores sea limitado y ello es posible "por la escasez de recursos naturales, la utilización del dominio público, la existencia de inequívocos impedimentos técnicos o en función de la existencia de servicios públicos sometidos a tarifas reguladas" [art. 17.1.c)].

Para el resto de los casos, distingue según se trate del puro acceso a la actividad económica o de la instalación e infraestructura física correspondiente. La autorización de la pura actividad económica sólo se podrá exigir "por razones de orden público, seguridad pública, salud pública o protección del medio ambiente en el lugar concreto donde se realiza la actividad". La autorización para la instalación o infraestructura física necesaria para la actividad económica sólo se podrá exigir "cuando sean susceptibles de causar daños sobre el medio ambiente y el entorno urbano, la seguridad y la salud y el patrimonio histórico-artístico". Como es fácil observar, desaparecen como causas justificativas de las autorizaciones muchas de las razones imperiosas de interés general: la preservación del equilibrio financiero del régimen de seguridad social, la protección de los derechos de los consumidores, de los destinatarios de servicios y de los trabajadores, las exigencias de la buena fe en las transacciones comerciales, la lucha contra el fraude, la propiedad intelectual e industrial, los objetivos de la política social y cultural... Todo esto puede justificar otras restricciones a las libertades económicas, pero no su sometimiento a autorización.

Esto no lo imponía el Derecho europeo ni siquiera tras la Directiva de Servicios ${ }^{11}$. Y tampoco lo impuso la Ley 17/2009 o "ley paraguas". De hecho, la LGUM modi-

\footnotetext{
${ }^{11}$ No debe confundir el hecho de que la corta lista de razones del art. 17.1.a) LGUM sí que coincide con la del art. 16.1.b) de la Directiva de Servicios: orden público, seguridad pública, salud pública y medio ambiente. Este precepto se refiere a los casos de prestación de servicios sin establecimiento en un Estado miembro a quien ya está establecido y presta servicios en otro; o sea, dentro de la genérica libertad de circulación de servicios, se refiere sólo a la libre prestación de servicios (arts. 56 a 72 TFUE) y no a la libertad de establecimiento (arts. 49 a 55 TFUE). Por el contrario, en el art. 17.1.a) LGUM estas pocas razones son las únicas que justifican autorizaciones en general, incluyendo ya no sólo al prestador de servicios implantado en una Comunidad que pretenda prestar-
} 
fica a ésta para adecuarla a su regulación. El cambio es revelador. Antes el art. 5.b) de esta Ley decía que se podía someter una actividad de servicios a autorización cuando hubiera "necesidad: que el régimen de autorización esté justificado por una razón imperiosa de interés general". Ahora, tras su modificación por la LGUM, dice: "Necesidad: que el régimen de autorización esté justificado por razones de orden público, seguridad pública, salud pública, protección del medio ambiente, o cuando la escasez de recursos naturales o la existencia de inequívocos impedimentos técnicos limiten el número de operadores económicos del mercado". O sea, menos razones que antes de la aprobación de la LGUM; no todas las imperiosas de interés general, como admitía la "ley paraguas", sino sólo algunas ${ }^{12}$.

Piénsese, por ejemplo, en los servicios de residencias para la tercera edad. Hasta la LGUM cabría que una Comunidad Autónoma los sometiera a autorización para, entre otras cosas, proteger "los derechos ... de los destinatarios del servicio ... y los objetivos de la política social”. Ahora eso mismo podrá justificar que las Comunidades Autónomas introduzcan en su normativa restricciones materiales a esas mismas residencias (cabrá imponer determinadas condiciones específicas a los edificios, ciertas instalaciones complementarias, requisitos mínimos de personal y de su cualificación, etc.) en tanto que ello quede amparado por razones imperiosas de interés general y sea proporcionado. Pero no podrá la normativa autonómica imponer un control previo del cumplimiento de todas esas condiciones mediante autorización ${ }^{13}$. Las que sí se permiten son fundamentalmente las autorizaciones urbanísticas, ambientales y muy poco más.

los en otra y ni siquiera sólo cuando quiera abrir establecimiento en otra, sino también, al margen de toda situación interautonómica, a quien por primera vez quiera prestar el servicio. Así que su equivalente en la Directiva de Servicios no es ese art. 16.1.b) sino el 9.1.b) en el que las autorizaciones se consideran justificadas por cualquier razón imperiosa de interés general. Si acaso podrá decirse que la LGUM juega hábilmente con expresiones y preceptos de la Directiva para construir otra cosa diferente.

${ }^{12}$ Esta restricción fue criticada en el Dictamen del Consejo de Estado sobre el Anteproyecto de LGUM (de 24 de junio de 2013, Ref. 631/2013), incluso sin entrar a valorar su afectación al sistema de distribución de competencias. Afirmó que las razones recogidas en el art. 17.1 "son insuficientes, debiendo expresamente remitir a las más amplias que señala el art. 5 (<<alguna razón imperiosa de interés general de entre las comprendidas en el art. 3.11 de la Ley 17/2009>>)".

${ }^{13}$ Vid. A. EZQUERRA HUERVA, "Los servicios sociales a la luz de la Ley de Garantía de la Unidad de Mercado", en M. J. ALONSO MAS (Dir.), El nuevo marco jurídico de la unidad de mercado. Comentario a la Ley de Garantía de la Unidad de Mercado, La Ley, Madrid, 2014, p. 820. Ello salvo que se acoja un concepto amplísimo de las pocas razones que según la LGUM justifican las autorizaciones. Es esto lo que parece estar intentándose sobre todo sirviéndose de un concepto desbocado de orden público, como veremos después en el apartado 5 de este mismo epígrafe II. 
Pero no sólo se va estrechando el cerco a las autorizaciones sino que la LGUM da un paso más y somete también a condiciones de necesidad, aunque más relajadas, el establecimiento de declaraciones responsables y de comunicaciones. A estos efectos, se rescata el concepto de razón imperiosa de interés general.

En concreto, el sometimiento a la condición de una declaración responsable es posible siempre que la actividad o instalación deba cumplir "requisitos justificados por alguna razón imperiosa de interés general y sean proporcionados". Las razones imperiosas de interés general, que antes podían justificar autorizaciones, son las que ahora pueden justificar declaraciones responsables. Aunque, para ser exactos, no se exige una razón imperiosa adicional para la declaración responsable sino que basta que exista un requisito material justificado por tales razones para que lo esté también esta declaración. Volviendo a nuestro ejemplo, sí que podría exigirse una declaración responsable sobre el cumplimiento de todos los requisitos impuestos a las residencias de la tercera edad.

Las comunicaciones, a las que no se califica de previas (pueden ser previas, simultáneas o posteriores), también quedan sometidas al principio de necesidad. Sólo caben, otra vez, "por alguna razón imperiosa de interés general". Pero a su vez se añade que lo que tales razones han de reclamar para imponerlas es que "las autoridades precisen conocer el número de operadores económicos, las instalaciones o las infraestructuras físicas en el mercado". No se tratará, parece, de un mero interés informativo o estadístico sino más bien de tener los datos mínimos e imprescindibles para poder ejercer el control y la inspección a posteriori ${ }^{14}$.

Más allá de los detalles y de las dudas que estos preceptos suscitan, lo importante es retener que el principio de necesidad extiende ahora su radio de influencia in-

${ }^{14}$ En ese sentido, J. J. PERNAS GARGÍA, "El principio de necesidad y de proporcionalidad en la Ley de Garantía de la unidad de Mercado", en M. J. ALONSO MAS (Dir.), El nuevo marco jurídico de la unidad de mercado. Comentario a la Ley de Garantía de la Unidad de Mercado, Le Ley, Madrid, 2014, p. 461.

Lo explicado concuerda con lo plasmado en los Acuerdos de las Comisiones Bilaterales de Cooperación de la Administración del Estado con las del País Vasco y Galicia. En ambos casos se dice: "El apartado 1 del art. 17 de la LGUM se interpretará en el sentido de que el mismo sólo rige para la exigencia de autorizaciones, de tal suerte que las razones imperiosas de interés general contenidas en el art. 3.11 de la Ley 17/2009, de 23 de noviembre, sobre libre acceso a las actividades de servicios y su ejercicio, justificarán las exigencias de presentación de declaraciones responsables o de comunicaciones previas, conforme prescriben los apartados 2 a 4 del referido art. 17 de la LGUM". Tal vez, esto se desprenda tan claramente de la LGUM que pueda considerarse superflua esta interpretación en la que lo único novedoso es que habla precisamente de "comunicaciones previas", cuando el art. 17.3 habla genéricamente de "comunicación", incluyendo, por tanto, a las comunicaciones simultáneas y posteriores. 
cluso sobre estas más modestas cargas formales que tras la Directiva de Servicios se presentaron como la alternativa suave a las autorizaciones y que, por tanto, también a este respecto se reducen las posibilidades de las leyes a las razones imperiosas determinadas por el legislador estatal.

$\mathrm{Al}$ igual que dijimos respecto al art. 5.1 LGUM, procede añadir aquí que todas las limitaciones del art. 17 LGUM a la imposición de autorizaciones, declaraciones y comunicaciones afectan especialmente a los legisladores autonómicos: claro está que un tratado internacional o cualquier normas de la Unión Europea puede prever autorizaciones sin tener que motivarlas en alguna de las razones seleccionadas por la LGUM; asimismo, el Estado podrá aprobar leyes que sometan actividades privadas a la obtención de una autorización sin que concurra algún de las razones del art. 17.1 LGUM o imponer declaraciones responsables o comunicaciones previas sin probar la justificación en alguna razón imperiosa de interés general. En sentido contrario, los entes locales no pueden someter ex novo una actividad a autorización ni siquiera aunque se trate de proteger proporcionadamente la más excelsa de esas razones imperiosas puesto que ello queda reservado a la ley ${ }^{15}$. Así que, insisto, son las leyes autonómicas las que sobre todo sufren las consecuencias del art. 17 LGUM, destacadamente las de su apartado 1. Y, concluido esto, vuelve a surgir la pregunta de antes ¿cabe que el Estado determine por su cuenta y con el carácter abstracto con que aquí se hace las razones por las que las Comunidades pueden imponer autorizaciones incluso en materias de exclusiva competencia autonómica? Diré prudentemente que, como mínimo, arduo resultará justificar una respuesta afirmativa que sólo con piruetas arriesgadas podría encontrar sustento en el art. $149.1 .1^{\text {a }}$ y $13^{\mathrm{a}} \mathrm{CE}$. Y añadiré únicamente que una respuesta negativa ofrecen no sólo la doctrina ${ }^{16}$ y varios conse-

${ }^{15}$ Por ello, dicho sea de paso, es de acierto más que discutible, o por lo menos induce a equívoco, el actual art. 84 bis de la Ley Reguladora de las Bases del Régimen Local que hace pensar que las entidades locales pueden decidir someter una actividad a autorización: si está regulando la intervención de las entidades locales en la actividad de los particulares, como hay que entender que hace y como se desprende del anterior art. 84, no tiene sentido que explicite las condiciones en que sí podrá someterse a licencia una actividad económica y menos aún que obligue a la Entidad Local a motivar ese sometimiento a autorización (apartado 3), porque, ni aun dándose esas condiciones, las entidades locales pueden decidir tal sujeción, lo que sólo puede hacer una norma con rango de ley y no, por tanto, las ordenanzas.

${ }^{16}$ G. FERNÁNDEZ FARRERES, "Unidad de mercado y libertades de empresa y circulación...”, cit., p. 129: “... parece más que dudoso que la LGUM se ajuste al orden constitucional de distribución de competencias por cuanto, según el reparto de las diversas materias, puede corresponder a las Comunidades Autónomas y no al Estado decidir sobre si las actividades quedan o no sujetas a autorización. Y, sin embargo, esa decisión queda ampliamente condicionada por el art. 17.1.a) y b) de la LGUM, al restringirse de manera anticipada las causas de necesidad que puedan legitimar o habilitar dicha decisión". 
jos autonómicos ${ }^{17}$, sino que la apuntó el propio Consejo de Estado y sobre todo el voto particular de uno de sus Consejeros ${ }^{18}$.

\section{El principio de proporcionalidad y el grado de restric- ción a las libertades económicas}

El principio de proporcionalidad cumple funciones muy diferentes: es un principio que debe presidir toda la intervención administrativa en la actividad de los particulares, como ahora consagra el art. 39.1 LRJAP; condiciona también al legislador en cuanto restrinja derechos fundamentales; etc. Pero, además, ha sido siempre esencial para valorar si una medida, pese a ser un obstáculo a la libre circulación, resulta admisible y conforme a la unidad de mercado, como ya recordábamos. Así, el TC considera contrarias al art. 139.2 CE las medidas que, aunque persigan una finalidad lícita, sean desproporcionadas. Y lo mismo aplica muy puntillosamente el Tribunal de Justicia respeto a las medidas que dificulten cualquiera de las libertades comunitarias de circulación. Esa proporcionalidad se descompone realmente en tres requisitos distintos que, aplicados a lo que nos ocupa, entrañan que la medida que alce una

17 Así, Dictamen 5/2014, de 14 de febrero, del Consejo de Garantías Estatutarias de Cataluña.

${ }^{18}$ Se trata del voto particular concurrente del Consejero Enrique Alonso García en el que afirma que el art. 17.1 LGUM "atenta muy gravemente tanto contra la autonomía constitucional de las Comunidades Autónomas como contra la lógica de la protección de múltiples bienes constitucionales...". El art. 17 LGUM, dice, "en realidad es un absurdo jurídico, pero un absurdo que, además, es contrario a la Constitución...”. Después dice: “... atenta contra bienes constitucionales y suprime la autonomía constitucional”. Razona así: “... sin la más mínima justificación, y sin examinar ni remitir a decisiones casos por caso o sector a sector (...) a través del análisis reposado de si tiene o no sentido y es proporcional al fin del interés general perseguido mantener las actuales o futuras prohibiciones o al menos someterlas a autorizaciones, el art. 17.1 propuesto (igual que el final art. 17.1 LGUM) levanta miles de prohibiciones..."; porque mantiene la posibilidad de autorización "exclusivamente en cuanto se trate de salvaguardar cuatro de las razones imperiosas de interés general muy concretas (...) prohibiendo totalmente salvaguardar, mediante esa técnica jurídica, las otras doce razones imperiosas de interés general". "Esta afirmación y mandato del art. 17.1 ... supone crear un mercado nacional, privando de competencias a las Comunidades Autónomas... Así pues, si en el mercado español se pretende que quienes tienen la competencia en esas doce áreas y que conforme al Derecho de la Unión podrían incluso adoptar medidas de prohibición ... no pueden someter las conductas de los operadores económicos que potencialmente atenten contra esos doce intereses generales a la técnica de la autorización, que es exactamente lo que dice el art. 17, el sistema es flagrantemente inconstitucional... Una norma general y abstracta que, como hace el art. 17, diga que queda prohibido someter a autorización actividades que atentan contra cualquiera de esos restantes doce principios, con independencia de su carencia total de sentido común, es, lisa y llanamente, inconstitucional...". 
dificultad a la unidad de mercado sólo superará el test de proporcionalidad si, primero, es real y efectivamente adecuada para el logro de la finalidad perseguida (congruencia con los motivos y adecuación al fin); si, además, es la menos restrictiva de las libertades de circulación de entre las que podrían satisfacer la finalidad pretendida (necesidad en sentido propio o favor libertatis); y si, por último, existe un equilibrio razonable entre la ventaja que la medida comporta para la finalidad perseguida y la restricción para la libertad de circulación que origina (proporcionalidad en sentido estricto).

Si siempre, en cualquiera de sus funciones, el principio de proporcionalidad comporta poner en relación dos variables, aquí esas variables son, de un lado, el beneficio de la medida para el interés general perseguido y, de otro, el perjuicio de la medida para la unidad de mercado, esto es, para la libertad de circulación concernida. Pero esto también sufre una transformación en la formulación de la LGUM.

Así, según la LGUM la primera variable ya no será el beneficio para cualquier interés general sino sólo para los comprendidos en las razones imperiosas de interés general, como ya sabemos. Y la segunda también es sorprendentemente alterada por el art. 5.2 LGUM en el que se comprueba que esta Ley está más preocupada por garantizar las libertades económicas que la unidad del mercado. No sólo porque someta a tal exigencia de proporcionalidad "cualquier límite o requisitos establecido conforme al apartado anterior" sin que importe mucho o poco que suponga una traba para la libre circulación sino porque curiosamente la severidad de la medida no se juzgará por la dificultad que erija a la unidad de mercado sino por la intensidad del límite a la libertad económica: “... habrá de ser tal que no exista otro medio menos restrictivo o distorsionador para la actividad económica”. En suma, se somete a este juicio de proporcionalidad a cualquier limitación a las libertades económicas, no a las que dificulten la unidad de mercado, y se las valora no por la intensidad de su afectación a esa unidad sino por su incidencia en las libertades de empresa y de profesión. Aunque esto pueda parecer bien, lo que es seguro es que ya no es la proporcionalidad que exige la unidad de mercado sino, si acaso, la de la libertad de empresa o, más ampliamente, la de las libertades económicas, incluyendo la de profesión y oficio. Quizás pueda mantenerse que esta exigencia de proporcionalidad de las restricciones a las libertades económicas es deducible directamente de la Constitución, aunque no haya tenido hasta ahora una gran efectividad práctica, y que,por tanto, rige lo diga o no esta Ley y frente al mismo legislador estatal por imperativo constitucional, no por imposición de la LGUM. O tal vez se pueda sostener que es una novedad de la LGUM en cuyo caso supondría un freno para las Comunidades Autónomas y los entes locales -sobre todo, como ya razonábamos, para el legislador autonómico- y no para otras leyes estatales. Pero, sea de una forma o de otra, insisto, no es propiamente la proporcionalidad que reclama la unidad de mercado sino otra cosa. 
Poco añaden los demás preceptos respecto al principio de proporcionalidad. Lo más significativo está otra vez en la regulación de los controles preventivos del art. 17 LGUM. Se reitera que el sometimiento a autorización, declaración responsable o comunicación, además de estar justificado por las razones que en cada caso se consideran legítimas, ha de ser proporcionado. Pero hay además específicos criterios de proporcionalidad. El más destacable es que sólo será proporcionada la sujeción a autorización cuando las concretas razones justificativas "no puedan salvaguardarse mediante la presentación de una declaración responsable o de una comunicación", de modo que, como es lógico, se consideran medidas más suaves éstas que aquélla.

\section{Necesidad, proporcionalidad y principio de precaución}

Merece reseñarse en este contexto la única alusión de la LGUM al principio de precaución [art. 17.1.d)] que, si se tomara al pie de la letra, supondría su exclusión del Derecho español.

En virtud de este principio -que proclaman diversas normas internacionales, europeas y españolas- se permite a los poderes públicos adoptar medidas restrictivas (o hasta prohibitivas) de una actividad, aunque sean ejercicio de las libertades económicas, cuando existan, aunque no absoluta certeza, indicios científicos fundados de su nocividad para ciertos intereses generales, sobre todo para la salud pública y el medio ambiente. Integrado este principio de precaución con el art. 5 LGUM, éste se debe interpretar así: las autoridades pueden establecer límites al acceso o al ejercicio de una actividad económica si son necesarios para salvaguardar alguna razón imperiosa de interés general, y se aceptará que hay tal necesidad cuando haya indicios científicos, aunque no una completa certeza, del daño para ese interés general (al menos, si se trata de la salud o del medio ambiente). Además, la proporcionalidad se enjuiciará en función de la nocividad que esos indicios científicos no definitivos le atribuyan. Igualmente, el art. 17 LGUM, sumado al principio de precaución, permitiría en su caso someter esa actividad "sospechosa" a autorización. El que ni el art. 5 ni el art. 17 LGUM se refieran específicamente al principio de precaución no sería óbice para esa interpretación que se derivaría del conjunto del ordenamiento.

Pero es el caso que, como anunciaba, sí que hay una específica mención del principio de precaución y sólo para referirse a los casos de sometimiento a autorización por disponerlo así "la normativa de la Unión Europea o tratados y convenios internacionales": sólo para tal hipótesis se dice que se tendrá en cuenta el principio de precaución ("incluyendo la aplicación, en su caso, del principio de precaución"). Como si ninguna norma nacional pudiera establecer restricciones, incluida la sujeción a autorizaciones, en aplicación del principio de precaución. Así que, en definitiva, la única mención de tal principio en la LGUM, lejos de suponer su reconocimiento y ad- 
misión, entraña más bien su exclusión como justificación de medidas limitativas puramente nacionales. Naturalmente, eso no impide que otra ley estatal disponga lo contrario para algún sector (alimentos, protección de aguas o montes, etc.). Pero, si no es así, ninguna Administración ni tampoco las leyes autonómicas podrán imponer limitaciones a las actividades económicas invocando el principio de precaución.

\section{El significado de cada una de las razones imperiosas; en particular, el orden público y las invocaciones al orden público en la legislación andaluza}

La trasposición de la Directiva de Servicios hizo ya necesario determinar qué haya de entenderse por "exigencias de la buena fe en las transacciones comerciales", "lucha contra el fraude", "objetivos de la política social y cultural"... y cada una de las acotadas como razones imperiosas de interés general. Ahora, con la LGUM, esa misma tarea alcanza aun mayor relevancia para nuestro Derecho interno puesto que del concepto que se dé a cada una de esas razones dependerá la mayor o menor posibilidad de imponer restricciones a las libertades económicas. Y si se trata de imponer precisamente la sujeción a previa autorización administrativa lo relevante será el concepto que se adopte de las más reducidas razones seleccionadas por la LGUM como justificativas de tal control previo: orden público, seguridad pública, salud pública y medio ambiente; o, si se trata de someter a autorización la instalación física, el entorno urbano, el patrimonio histórico-artístico y poco más. Lo cierto es que no es una tarea del todo sencilla. Dado el origen del concepto de razones imperiosas de interés general y la misma forma de definirlas del art. 3.11 de la Ley 17/2009 (la "ley paraguas" que, recuérdese, dice "razón definida e interpretada por la jurisprudencia del Tribunal de Justicia...”), parece obligado acudir a la jurisprudencia del Tribunal de Luxemburgo para delimitar, incluso a efectos internos, qué haya de entenderse por cada una de esas razones. Sin detenernos a analizar este singular fenómeno de remisión del legislador a la jurisprudencia -más aún, de remisión del legislador estatal y para cuestiones de Derecho interno a la jurisprudencia del Tribunal europeo construida con otra base y a otros efectos-, por más que sea un fenómeno casi paranormal, lo cierto es que esto podrá facilitar la tarea y dar en muchos casos datos fundamentales. Pero, incluso así, no se resolverán todas las dudas.

Quizás el concepto más problemático sea el de orden público que, como hemos visto, aparece en la LGUM como la primera razón imperiosa de interés general y como una de las pocas y más reducidas capaces de justificar el sometimiento a autorización. El orden público es un concepto clásico donde los haya, y también un concepto difícil como pocos; necesario, pero difícil y hasta peligroso. Siempre ha jugado como un límite de las actividades de los ciudadanos, incluidas especialmente las que se presenten como ejercicio de sus derechos fundamentales (así aparece en los trata- 
dos internacionales sobre derechos humanos) o de la autonomía de la voluntad; incluso como límite a la costumbre, a la aplicación de normas extranjeras, a la renuncia de derechos... Y, casi como el reverso de la misma moneda, ha servido también como título de potestades públicas, sobre todo de potestades administrativas de intervención sobre los particulares. Para el liberalismo era casi el único límite esencial a las libertades públicas, incluidas las económicas, y el titulo legitimador por antonomasia de potestades administrativas sobre los particulares, aunque precisamente por ello se acogía un concepto de orden público relativamente reducido. Un concepto que se fue ampliando y deformando según las necesidades de cada época (se habla incluso de un orden público económico) o hasta pervirtiendo para justificar la represión política.

Ahora con la LGUM retoma brío e importancia. Pero no por ello adquiere perfiles más nítidos. Por el contrario, se hace aún más difícil. Porque si ha sido habitual identificarlo con seguridad, salubridad y tranquilidad públicas (a veces, también, con moralidad pública), ahora, en la LGUM -como antes en la Directiva de Servicios y en la ley paraguas- aparece siempre junto a "la seguridad pública" y "la salud pública". Así que, si no es la seguridad pública ni la salud pública, se plantea aún más cruda y enigmáticamente su concepto y delimitación. De su vaporoso contenido y borrosas fronteras dan testimonio algunas sentencias del Tribunal de Justicia e incluso hay vestigios de ello en la Directiva de Servicios. Es sugerente su considerando 41: "El concepto de orden público, según lo interpreta el Tribunal de Justicia, abarca la protección ante una amenaza auténtica y suficientemente importante que afecte a uno de los intereses fundamentales de la sociedad y podrá incluir, en particular, temas relacionados con la dignidad humana, la protección de los menores y adultos vulnerables y el bienestar animal". Por su parte, la misma Exposición de Motivos de la LGUM ha tenido interés en aclarar que en el orden público "se incluyen, entre otras, la prudencia y la garantía de la estabilidad financiera".

Si ya lo anterior es suficiente para poner de relieve la versatilidad y potencialidad de este concepto, el ejemplo de la Ley andaluza 3/2014, de 1 de octubre, de medidas normativas para reducir las trabas administrativas a las empresas, es aún más ilustrativo. Para adaptar el ordenamiento andaluz a la LGUM, enumera en sus Anexos las actividades que seguirán necesitando autorización así como la concreta razón que en cada caso lo justifica. De las 130 actividades que cita como sujetas a autorización, 65 aparecen con la única justificación del orden público. Entre ellas, por ejemplo, casi todas las relacionadas con el juego (casinos, bingos, aparatos mecánicos para la mezcla automática de naipes, apuestas hípicas, apuestas deportivas, publicidad de juegos, explotación de máquinas activas de azar, tómbolas, etc.) pero también con Cajas de Ahorros (fusiones, escisiones, cesión global del activo o pasivo, ejercicio indirecto de la actividad financiera a través de una entidad bancaria, etc.) y otras variadas como el funcionamiento de hipódromos o la enseñanza bilingüe en centros de 
titularidad privada. Para otras 10 actividades que seguirán necesitando autorización el orden público aparece como justificación junto con alguna otra razón. Así, la autorización de funcionamiento de un servicio social se mantiene por razones de orden público y de salud pública ${ }^{19}$; la de horarios especiales en establecimientos de hostelería en municipios turísticos subsiste por orden público, seguridad pública y protección del medio ambiente; la de emisiones en cadena televisiva o la de instalación o modificación de las estaciones transmisoras se mantiene por orden público y por la limitación del número de operadores. Nada me atrevo a objetar a la supervivencia de todas esas autorizaciones sin un estudio de cada una de ellas. Ni siquiera oso hacer reparos a su profusa y exuberante invocación del orden público. Pero resulta casi inevitable no recordar ante todo esto la conocida obra de Lorenzo Martín-Retortillo cuyo título era y vuelve a ser bien elocuente: "La cláusula de orden público como límite -impreciso y creciente- al ejercicio de los derechos". Cuando se publicó en 1975 tenía un sentido y ahora otro muy distinto. Quizá, incluso, las mismas fuerzas políticas que antes veían con más que recelo cualquier mención del orden público lo enarbolen ahora para legitimar frenos a la libertad de empresa. Pero existe algún fondo común.

Incluso otras razones imperiosas de interés general de fronteras aparentemente más claras no dejarán de suscitar dudas. De nuevo, la referida ley andaluza suministra ejemplos sugerentes. Así, mantiene la autorización "habilitación de guía de turismo"; razón justificativa: "Patrimonio histórico respecto a sus instalaciones, bienes integrantes del catálogo general del patrimonio histórico andaluz". ¿Realmente la actividad de estos guías turísticos puede causar "daños sobre... el patrimonio históricoartístico"? En cualquier caso, esos daños justifican según la LGUM autorizaciones a las instalaciones o infraestructuras físicas, no a la mera actividad, que es lo que la ley andaluza sujeta a ese control administrativo. ¿No es lo cierto que la exigencia de habilitación para ejercer como guía de turismo obedece a razones distintas? Si acaso, por conectarlas con algunas de las imperiosas de interés general, se podrían invocar "objetivos de la política... cultural". Pero recuérdese que, aunque tales objetivos son razones imperiosas de interés general, no son de aquéllas pocas en las que la LGUM permite fundamentar el sometimiento a autorización.

19 Sobre el caso concreto de los servicios sociales y la justificación de limitaciones y de sometimiento a autorización por razones de orden público es muy interesante A. EZQUERRA HUERVA, "Los servicios sociales a la luz de la Ley de Garantía de la Unidad de Mercado", cit., pp. 810 y 819. Allí se comprueba que ya antes de la LGUM algunos legisladores autonómicos habían invocado el orden público como justificación de las autorizaciones para servicios sociales y cómo el autor lo admite para el pasado y para el futuro, por más que pueda parecer un uso desorbitado del concepto de orden público. 


\section{EL PRINCIPIO DE EFICACIA EN TODO EL TERRITORIO NACIONAL}

\section{Eficacia nacional de normas y de controles previos de las autoridades infraestatales. Determinación de las autori- dades de origen y de destino}

Muchas de las novedades de la LGUM son consecuencia o concreción de lo que la Ley denomina "principio de eficacia de las actuaciones de las autoridades competentes en todo el territorio nacional", que proclama en su art. 6 y cuyo contenido y alcance remite a lo establecido en su Capítulo V, esto es, a sus arts. 19 y 20. Puede afirmarse, más en concreto, que el art. 19 LGUM se ocupa de la eficacia nacional de las normas de entes infraestatales (sobre todo de las Comunidades Autónomas) y que el art. 20 lo hace de la eficacia nacional de los controles administrativos previos realizados por esos mismos entes. Lo verdaderamente cardinal es lo que se consagra en el art. 19, y lo dispuesto en el art. 20 es más bien una consecuencia o, como máximo, un complemento.

Simplificando mucho, se trata de dar eficacia nacional a ciertas decisiones (normativas y ejecutivas) de las autoridades de origen que, por eso, constreñirán las posibilidades regulatorias de las autoridades de destino. Y basta esto para comprender que se convierte en presupuesto necesario y capital la determinación del lugar de origen y del lugar de destino o, para ser más exactos, de la autoridad de origen y de destino. La definición de ambas autoridades se contiene en el Anexo de la Ley, apartados c) y d). Estas definiciones parecen inspiradas por las que daba la Directiva de Servicios para "Estado miembro de establecimiento" y "Estado miembro de destino". Por eso mismo son insuficientes para todo lo que regula la LGUM que se ocupa también de los productos. Es eso lo que explica que la LGUM utilice también otro concepto, el de "autoridades del lugar de fabricación" [art. 21.2.c)] que, aunque no aparece en su Anexo, no es idéntico al de autoridad de origen.

Autoridad de origen es la "competente del lugar del territorio nacional donde el operador esté establecido legalmente para llevar a cabo una actividad económica", entendiendo a su vez por tal aquél en el que "acceda a una actividad económica y a su ejercicio". Acaso sobran algunos elementos en esa definición; en especial el adverbio "legalmente". Creo, más bien, que la autoridad de origen puede definirse simplemente como aquélla que tiene competencia en el lugar en que el operador accede a la actividad económica. Puede tratarse de una autoridad autonómica (sea su Parlamento o sea una autoridad administrativa) o local o corporativa (especialmente de la organización de colegios profesionales); incluso de algún organismo privado de normalización o acreditación en tanto actúe como colaborador de la Administración. Si accede a la actividad en Santander, la autori- 
dad de origen será, según la actividad de que se trate y las diferentes competencias alguna de la Comunidad Autónoma cántabra o la del municipio o la del colegio profesional respectivo..., y ello con independencia de que lo haga legal o ilegalmente.

Autoridad de destino es la "competente del territorio nacional donde un operador legalmente establecido en otro lugar del territorio nacional lleva a cabo una actividad económica, con establecimiento o sin él". De nuevo creo que sobra el "legalmente" y de nuevo la definición incluye a autoridades autonómicas, locales, corporativas -incluso a organismo privados colaboradores de la Administración-, según quien tenga la competencia para regular y controlar la actividad de que se trate en ese lugar de destino.

No siempre será fácil determinar con estas definiciones cuál sea el lugar de origen y cuál, en consecuencia, la autoridad de origen. Consciente de ello el legislador introdujo en la tramitación parlamentaria, concretamente en el Senado, la disposición adicional $10^{a}$ sobre "determinación de la autoridad de origen" para dos tipos de casos: "cuando en aplicación de la definición prevista en la letra d) del anexo de esta Ley haya conflicto para determinar cuál es la autoridad de origen" y cuando "el operador se haya establecido en más de un lugar". En ambos casos se da al operador libertad para elegir como autoridad de origen "la de cualquiera de los lugares en que se haya establecido" con la sola condición de comunicar su opción a "las autoridades afectadas". Sólo en tanto no ejerza tal opción esta disposición establece otras dos reglas cuya relación entre sí no resulta clara: o bien será autoridad de origen la del lugar "en el que se estableció en primer lugar" o bien en aquél en el que "ejerce la dirección efectiva de su actividad económica, centraliza la gestión administrativa y la dirección de sus negocios".

Sea como fuere, lo cierto es que a efectos de supervisión de los productos el art. 21.2.c) LGUM utiliza otro concepto, el de "autoridades del lugar de fabricación". No lo define en ningún momento y ni se menciona en el Anexo ni en la referida disposición adicional $10^{\mathrm{a}}$. Aun así, no parece que se pueda identificar con el del lugar de origen. Así, si un mismo operador tiene varias fábricas, la autoridad de origen sería a su elección la del territorio de cualquiera de ellas o, si no hace tal elección, la del lugar donde ejerza la dirección efectiva, centraliza la gestión administrativa y la dirección de sus negocios o aquélla en que primero se estableció. Pero "autoridades del lugar de fabricación" serán aquéllas del territorio en que esté cada fábrica y, por tanto, si un mismo operador tiene varias fábricas en Comunidades diferentes, cada una de ellas estará sometida a estos efectos de supervisión a autoridades distintas. 


\section{Eficacia nacional de las normas}

A) Reconocimiento mutuo de las regulaciones y suficiencia del cumplimiento de la normativa del lugar de origen

La eficacia nacional de las normas infraestatales, en especial, autonómicas, tal y como aparece en el art. 19 LGUM, comporta el equivalente interno a los principios europeos del reconocimiento mutuo y del país de origen, aunque en una versión extrema. Un reconocimiento mutuo que entraña que quien realice una actividad económica en cualquier lugar de España tiene abiertas las puertas a cualquier otro lugar del territorio nacional. El desconcertante rubro con el que se encabeza este art. 19 LGUM -"libre iniciativa económica en todo el territorio nacional"- da en realidad pistas certeras de lo que acaba significando y de lo que busca el legislador: el operador ya establecido en cualquier lugar de España tiene libertad económica en todo el territorio nacional. A partir del momento de su establecimiento inicial tiene libertad para elegir su ámbito espacial de actuación dentro de España.

Para los operadores económicos el principio de eficacia nacional de las normas supone que les basta cumplir con la normativa y con los requisitos del lugar de España en que estén establecidos (lugar de origen) para poder prestar sus servicios o vender sus mercancías en cualquier otra parte del territorio nacional, aunque no cumplan con la normativa o con los requisitos formales exigidos en el lugar de destino. Es justamente esto, y desde esa misma perspectiva, lo que proclaman los dos primeros apartados del art. 19 LGUM:

1. Desde el momento en que un operador económico esté legalmente establecido en un lugar del territorio español podrá ejercer su actividad económica en todo el territorio, mediante establecimiento físico o sin él, siempre que cumpla los requisitos de acceso a la actividad del lugar de origen...

2. Cualquier producto legalmente producido al amparo de la normativa de un lugar del territorio español podrá circular y ofertarse libremente en el resto del territorio desde el momento de su puesta en el mercado.

Así que si el lugar de origen del operador económico es, por ejemplo, Cataluña, cumpliendo las normas de esa Comunidad Autónoma ese operador podrá vender productos o prestar servicios en cualquier otra Comunidad. El corolario es que no se puede exigir el cumplimiento de la normativa del lugar de destino ni ninguno de sus requisitos. Esta otra cara de la misma moneda la enuncia así el último apartado de ese art. 19:

3. Cuando conforme a la normativa del lugar de destino se exijan requisitos, cualificaciones, controles previos o garantías a los operadores económicos o a los 
bienes, distintos de los exigidos u obtenidos al amparo de la normativa del lugar de origen, la autoridad de destino asumirá la plena validez de estos últimos, aunque difieran en su alcance y cuantía...

Más que "asumir la plena validez", lo que no se discute ${ }^{20}$, se trata de que las autoridades de destino han de asumir la eficacia en su territorio; o, mejor, han de asumir como suficiente para la comercialización de servicios y mercancías el cumplimiento de la normativa y los requisitos del lugar de origen, sin que pueda exigir ninguna otra condición material ni formal en virtud de su propia normativa. Es en ese sentido en el que se puede decir que la normativa del lugar de origen tendrán eficacia nacional; y en ese mismo sentido cabe afirmar también que, en tanto sea autonómica o local, tendrá una eficacia extraterritorial, es decir, más allá del espacio en que ejercen sus competencias los órganos que la aprobaron, hasta cubrir todo el territorio nacional. No es propiamente que rijan fuera de su territorio, pero sí que tendrán efectos jurídicos más allá de su territorio.

El mismo reconocimiento mutuo se da hasta cuando en la Comunidad de origen no haya ninguna regulación o la que haya no imponga ninguna restricción ni condición. Lo admite expresamente el apartado 1 in fine del mismo art. 19: la suficiencia del cumplimiento de la normativa del lugar de origen se da "... incluso cuando la actividad económica no esté sometida a requisitos en dicho lugar"; y lo reitera el último inciso del art. 19.3: "Asimismo, el libre ejercicio operará incluso cuando en la normativa del lugar de origen no se exïa requisito, control, cualificación o garantía alguno".

${ }^{20}$ No es exactamente que no se discuta o no se pueda discutir su validez. Sobre eso no incide la LGUM y tras ella la autoridad de destino podrá eventualmente discutir la validez de las normas o de los actos de la de origen; es más, ahora podrá hacerlo con más razón que antes puesto que aquellas normas y aquellos actos de la autoridad de origen le van a afectar más. De hecho, en el Acuerdo de la Comisión Bilateral de Cooperación de la Administración del Estado y del País Vasco se ha aclarado que "la asunción de la plena validez de los regímenes de acceso determinados por las autoridades de origen se entenderá sin perjuicio de que puedan ejercitarse todos los medios de impugnación oportunos conforme a Derecho". Incluso cabe añadir que habría hecho bien la LGUM si hubiera consagrado expresamente la legitimación de las autoridades de destino para recurrir las normas y los actos de las autoridades de origen que ahora van a afectar tanto a su territorio. En cualquier caso, lo que se quiere consagrar en el precepto comentado, aunque lo exprese equívocamente, es que la autoridad de destino, además de respetar la presunción de validez de las normas y de los actos de la autoridad de origen en tanto no se anulen por los medios ordinarios (incluso aunque los crea nulos de pleno derecho), ha de aceptarlos como eficaces y suficientes para comercializar el bien o servicio en su territorio. No se trata de aceptar su validez; ni siquiera de aceptar su eficacia; sino de aceptar su suficiencia en el propio territorio sin cumplir ningún requisito más, no material ni formal. 
Casi huelga decir que la normativa del lugar de destino no se aplicará a ese operador foráneo aunque se trate de normas indistintamente aplicables a esos y a los operadores locales. Es más, ese será el supuesto ordinario. Una norma autonómica o municipal que estableciera condiciones específicas para los de fuera sería antes condenada por discriminatoria. Son las normas indistintamente aplicables a todos, los de dentro y los de fuera, las que no se podrán oponer al operador ya establecido en otro lugar.

En suma, lo que se consagra es la suficiencia del cumplimiento de la normativa del lugar de origen (sobre todo, de la Comunidad de origen) y la imposibilidad de oponer al operador de fuera ningún requisito o condicionamiento fijado en las normas aprobadas por la autoridad del lugar de destino (sobre todo, de la Comunidad de destino).

B) No cabe exigir el cumplimiento de la normativa de destino ni siquiera por las más valiosas razones imperiosas de interés general

Es de destacar que, a diferencia de lo que sucede en la Unión Europea, este obligado reconocimiento mutuo entre los diversos entes, en particular, entre diversas Comunidades Autónomas, y la sujeción única a la regulación de la Comunidad de origen no admite excepciones basadas en ninguna razón imperiosa de interés general ni siquiera ante la prueba de que la legislación de origen no satisface el interés general en el nivel que la legislación de destino considera adecuado ni aunque se demuestre que la medida de esa autoridad de destino es necesaria y proporcionada para tal finalidad; ni siquiera aunque la norma de destino sea indistintamente aplicable a todos y aunque se pruebe que ni siquiera de hecho perjudica más a los de fuera. A este respecto, ni las razones imperiosas de interés general ni alguna de las más cualificadas de ellas (p. ej., salud pública) permiten matización de ningún género.

Esto debe retenerse y enfatizarse: si antes, al analizar el principio de necesidad de la LGUM, ya notamos cómo se habían reducido las razones imperiosas de interés general y cómo se las había erigido en la única justificación de las restricciones a las libertades económicas, lo que de ninguna forma son en Europa, ahora vemos que en España se les niega la función que sí tienen allí, esto es, la de posible justificación de las trabas a la libre circulación derivadas de normas indistintamente aplicables. Obsérvese bien la diferencia, que no es menor: en Europa las razones imperiosas de interés general (o, las exigencias imperativas) no son necesarias para justificar límites a la libertad de empresa y de profesión pero en España, con la LGUM, sí; en Europa las razones imperiosas de interés general (o las exigencias imperativas) legitiman obstáculos a la libre circulación derivados de normas estatales indistintamente aplicables a nacionales y extranjeros comunitarios, pero en España ni ellas (ni 
siquiera alguna de ellas especialmente importantes, v. gr., salud pública) legitimarán obstáculos a la libre circulación derivadas de normas autonómicas indistintamente aplicables a los operadores de dentro y de fuera. Una vez más se comprueba que, con sonido parecido al del Derecho europeo, las soluciones de la LGUM son distintas y más radicales.

Además, debe notarse que la normativa de la Comunidad de destino, en virtud del previo principio de necesidad, sólo pudo imponer, incluso para sus propios operadores y productos, restricciones por razones imperiosas de interés general. Y, pese a ello, en virtud de este otro principio, no podrá oponerlas al operador o al producto de otra Comunidad. Así, en realidad, si este principio de eficacia nacional admitiese excepciones por razones imperiosas de interés general sería ocioso por redundante porque ya se supone que las restricciones previstas por la regulación de destino están fundadas en ellas. Pero no deja de ser chocante la suma de los dos principios con el resultado de que no se puede exigir la observancia ni de normas que hay que suponer que sólo imponen lo imprescindible para preservar los intereses más valiosos.

Naturalmente, todo esto no sólo es distinto de lo que rige en la Unión Europea sino también supone un cambio radical respecto a la situación anterior en España. Sirvámonos del ejemplo que nos suministra la STC 66/1991 que aceptó la constitucionalidad de la norma castellano-leonesa que prohibía la venta de cangrejos vivos de río de cualquier especie en el territorio de esa Comunidad Autónoma por entender que, pese a que obstaculizaba la libre circulación de bienes, era una medida proporcionada para garantizar la preservación de los cangrejos autóctonos e impedir la transmisión de la afanomicosis, esto es, razones ambientales y de sanidad animal. Una medida como ésa sería ahora, aunque conforme con el principio de necesidad (pues sus fines entran en las razones imperiosas de interés general), contraria al principio que analizamos: vulneraría abiertamente el art. 19 LGUM y, más en concreto, su apartado 2 en cuanto que impediría que un producto legal en otras Comunidades Autónomas se ofertase en Castilla y León. No hay que irse a ejemplos tan peculiares. En realidad, hasta las más típicas medidas previstas en la Ley de Sanidad Animal, ley estatal pero de ejecución predominantemente autonómica, pueden ponerse en cuestión en tanto que limiten la libre circulación de animales vivos o muertos o productos de origen animal entre distintos lugares de España aunque sean imprescindibles para luchar contra epizootias o incluso contra zoonosis. Y lo mismo podríamos decir de las medidas autonómicas de lucha contra las plagas de cultivos o tantas otras. 
C) En especial, la suficiencia de cumplimiento de las normas de origen en cuanto a los productos

En cuanto a los productos, este principio de eficacia de las normas en todo el territorio nacional consagrado en la LGUM no tiene límites ni matizaciones. No sólo es que, a diferencia de lo que sucede en el Derecho de la Unión, no se admitan aquí excepciones por ninguna razón, como ya se ha explicado, sino que rige para todos los aspectos del producto: si una mercancía se ha elaborado, producido o fabricado conforme a la normativa de la Comunidad de origen, podrá ofertarse en cualquier otra Comunidad sin ninguna limitación y sin tener que hacer adaptación de ningún género para acomodarse a la normativa de ésta. Así se desprende del transcrito art. 19.2 LGUM que ni siquiera diferencia entre las condiciones materiales de la mercancía (requisitos del centro de producción, composición, formas de elaboración y conservación...) y las de presentación (denominación, envase, etiquetado, información, dimensión, peso, acondicionamiento...).

Además, el precepto dice que el producto "podrá circular y ofertarse libremente" por lo que a la Comunidad Autónoma de destino no le cabe tampoco restringir los cauces y modalidades de distribución comercial (por ejemplo, no podrá prohibir su venta a domicilio o ambulante o exigir su comercialización en farmacias u otro establecimiento especializado o limitar su publicidad, o restringir su uso a profesionales, etc., aunque eso rija para sus propios productos $)^{21}$.

Parece, incluso, que esa libre circulación sólo está condicionada a que se haya producido legalmente en una Comunidad Autónoma, sin que se exija que haya llegado a comercializarse efectivamente en ella ${ }^{22}$.

${ }^{21}$ En esto también se diferencia de la solución de la Unión Europea donde la regulación de las denominadas "modalidades de venta" tienen un régimen específico menos severo que el relativo a las condiciones de los productos. Vid. M. REBOLLO PUIG, "El mercado interior europeo y la ordenación estatal de comercio interior. En especial, la libre circulación de mercancías y la Directiva sobre prácticas comerciales", en la obra colectiva dirigida por mí mismo Regulación económica. IX. Comercio interior, Iustel, Madrid, 2013, II, pp. 392 a 404. La LGUM, por el contrario, no permite de ninguna forma distinguir entre condiciones del producto y modalidades de venta.

22 Es otra diferencia con el Derecho europeo en el que, desde la Comunicación de la Comisión de 3 de octubre de 1980, no basta que el producto esté legalmente fabricado en el Estado de origen sino que es necesario también que "se comercialice en el territorio de este último". Con lo cual se trata de evitar que se beneficien del reconocimiento mutuo las mercancías elaboradas en un Estado con la sola finalidad de venderlas en otros, freno que tampoco encuentra reflejo en el art. 19.2 LGUM. Parece insuficiente para salvar esta objeción el que este art. 19.2 termine condicionando la libre circulación del producto al "momento de su puesta en el mercado". 
D) En especial, la suficiencia de cumplimiento de las normas de origen en cuanto a actividades económicas; distinción entre acceso y desarrollo de la actividad

Más obscuro es el ámbito de este principio en cuanto a las actividades económicas. Lo que sobre todo es dudoso es si se trata sólo de los requisitos de acceso a la actividad o si también incluye los requisitos de ejercicio de la actividad. El art. 6 LGUM habla de "libre acceso y ejercicio de la actividad". El art. 19.1 LGUM se refiere concretamente a "los requisitos de acceso a la actividad". Y en el apartado 3 del mismo art. 19 ya no se habla concretamente de requisitos de acceso sino de todos en general.

La interpretación que se ha acogido y se ha plasmado los Acuerdos de las Comisiones Bilaterales de Cooperación de la Administración del Estado con el País Vasco y con Galicia es la que entiende que se trata sólo de los requisitos de acceso; o sea, que en cuanto a los requisitos y condicionantes de todo género relativos al ejercicio de la actividad sí sería oponible al operador foráneo la normativa del lugar de desti$n^{23}$. Démosla por buena, aunque la literalidad de los preceptos no es clara, entre otras razones porque seguramente es la interpretación más conforme con la Constitución. Por tanto, lo que domina la autoridad de origen son las condiciones de todo tipo (titulaciones profesionales, certificados, seguros, autorizaciones, etc.) para el acceso a la actividad, para la "iniciativa económica", como dice el rubro del art. 19; y

Lo único que queda al margen del art. 19.2 LGUM son los productos que, aunque procedentes de una Comunidad Autónoma, no se hayan producido en ella sino en otro Estado, pero ello es sólo porque se supone que si ese producto extranjero ya se comercializa legalmente en algún lugar de España es porque así lo ha permitido el Estado y no ninguna autoridad subestatal.

${ }^{23}$ En el Acuerdo con el País Vasco se lee: "El inciso $<<$ la autoridad de destino asumirá la plena validez de estos últimos>> contenido en el art. 19.3 de la LGUM, se entenderá en el sentido de que las autoridades de destino asumirán la plena validez de los requisitos, cualificaciones, controles previos o garantías exigidos por las autoridades de origen para acceder a una determinada actividad económica, sin que tal asunción alcance al régimen de ejercicio que las autoridades de destino establezcan en su territorio". Exactamente lo mismo se dice en el Acuerdo con Galicia, donde además aparece esta otra aclaración: “... ambas partes coinciden en interpretar que la referencia del art. 19.3 a los requisitos, cualificaciones, controles previos, garantías o actuaciones administrativas exigidos conforme a la normativa del lugar de destino que sean distintos a los exigidos al amparo de la normativa del legal de origen, se refiere exclusivamente a aquellas que estén relacionadas con el acceso a la actividad y no a las condiciones de ejercicio establecidas por la autoridad de destino, siempre y cuando éstas se justifiquen por razones imperiosas de interés general y no resulten discriminatorias ...". O sea que esa regulación de la autoridad de destino sobre el ejercicio de la actividad sí es exigible a condición de que respete los otros principios de la LGUM, esto es, los de necesidad (incluida, hay que entender, la proporcionalidad) e igualdad. 
a ese respecto puede decidir con igual fuerza y efectos extraterritoriales no imponer ninguna. Pero cuando el operador preste servicios en otra Comunidad Autónoma, con o sin establecimiento, quedará sometido a la regulación de ésta (de la de la autoridad de destino) en cuanto al desarrollo de la actividad. Así, si la prestación de servicios de reparación de automóviles o de tintorería, por ejemplo, es desarrollada por una empresa navarra en Aragón, en el ejercicio de su actividad (así, entre otras cosas, deberes de información a los consumidores, vías de reclamación, etc.) quedará sometida a la normativa aragonesa, sin que la normativa de la autoridad de origen, la navarra en el ejemplo, le persiga como si fuese un fuero personal que le exime de la regulación del lugar de prestación (el de la autoridad de destino, en la terminología legal).

Aun así, muchas dudas subsisten. Por lo pronto, ni el art. 6 ni el 19 LGUM dejan claro que se estén refiriendo sólo a actividades de servicios, como parece más lógico, y no a todas las actividades económicas, incluyendo, por tanto, conforme al Anexo de la propia LGUM, hasta las de producción de bienes. Incluso suponiendo que se refiera únicamente a la prestación de servicios, el art. 19.1 permite al operador no ya simplemente prestarlos en otro lugar -en otra Comunidad Autónoma, para nuestros efectos- sino establecerse en él pues se dice que podrá ejercer su actividad "mediante establecimiento físico o sin él". O sea, que no se distingue entre la pura libertad de prestación de servicios (sin establecimiento, ya sea con desplazamiento o sin él) y la libertad de establecimiento (que puede ser con filiales, sucursales...). Finalmente, será a veces difícil fijar la frontera entre condiciones de acceso y condiciones de ejercicio de la actividad. Piénsese, por ejemplo, en la actividad de enseñanza de idiomas. Quién ya realice legalmente esa actividad en una Comunidad Autónoma ¿podrá abrir academias libremente en cualquier otra? ¿tendrá o no que cumplir las normas de la Comunidad de destino sobre las condiciones físicas de las academias, sobre medios pedagógicos, sobre ratio profesor/alumnos, sobre titulación del profesorado? O sea, ¿son ésas condiciones de acceso o condiciones de ejercicio? Y lo mismo podríamos decir de los gimnasios, de los centros de estética, de diversos servicios sociales... sin que la LGUM permita respuestas fáciles.

\section{Eficacia nacional de los actos de control previo}

A) La suficiencia del control de origen y la correlativa prohibición del control de destino

El principio de eficacia nacional de las normas del art. 19 LGUM encuentra su concreción y complemento en el art. 20 que consagra, según su tenor literal, la "eficacia en todo el territorio nacional de las actuaciones administrativas". Este rótulo no es exacto sino sólo aproximativo. 
Por lo pronto, la eficacia nacional que se predica sólo tiene interés para las Administraciones infraestatales, no para la estata ${ }^{24}$. En realidad, sólo es novedosa para las actuaciones de las Administraciones autonómicas y locales ${ }^{25}$.

Por otra parte, no se ocupa sólo de actuaciones propia y directamente administrativas sino también, aunque en ejercicio de funciones públicas o como complemento de ellas, de las realizadas por organismos privados de evaluación, acreditación, certificación y similares en tanto que actúen para una Administración infraestatal. Y asimismo se ocupa de actuaciones de los administrados como son las declaraciones responsables y las comunicaciones cuando se realizan ante una Administración infraestatal, sobre todo si se hacen en cumplimiento de una norma igualmente infraestatal.

Por último, aquí no se da eficacia nacional a cualquier actuación administrativa sino sólo a "los medios de intervención" que permitan el acceso a una actividad económica o su ejercicio o producir o comercializar ciertos bienes o servicios o contratar con el sector público u obtener subvenciones o beneficios fiscales. Y ello porque acrediten el cumplimiento de ciertas calidades, cualificaciones profesionales u otras circunstancias. Incluye desde luego prototípicamente a muchas autorizaciones o licencias, pero también a habilitaciones, certificaciones, acreditaciones, reconocimientos oficiales, inscripciones en registros..., además de las ya aludidas declaraciones responsables y comunicaciones realizadas por los mismos administrados. Están incluidos todos los medios de control previo exigidos para realizar actividades puramente privadas en ejercicio de la libertad de empresa o profesión, pero también algo más porque se alude expresamente a actos necesarios para contratar y para obtener ventajas públicas. Por tanto, en suma, se trata de la eficacia nacional sólo de ciertos ac-

${ }^{24}$ Cuando se trata de la Administración del Estado o de cualquiera de sus entes institucionales la eficacia en todo el territorio nacional va de suyo y se encarga de recordarla, acaso ociosamente y con condicionamientos que parecen superfluos, la disposición adicional primera de la misma LGUM.

${ }^{25}$ En cuanto a los Colegios Profesionales una regla similar regía con anterioridad. En concreto, me refiero al art. 3.3 de la Ley de Colegios Profesionales en la redacción que le dio la Ley 25/2009. Allí ya se establece que cuando hay varios colegios territoriales "bastará la incorporación a uno sólo de ellos, que será el domicilio profesional único o principal, para ejercer en todo el territorio español". Y si en la Comunidad en el que se tiene tal domicilio no hay colegio o la colegiación no es obligatoria, sin ese requisito se podrá ejercer en toda España. Y ello sin que en ningún caso el Colegio del lugar en el que se ejerza distinto del domicilio profesional pueda exigir comunicación ni contraprestación de ningún tipo. Con ese precedente, el art. 20 LGUM no comporta, según creo, ninguna novedad para los Colegios Profesionales y hasta puede pensarse que lo que hace ahora la LGUM es extender a todos los ámbitos lo que ya regía para las profesiones colegiadas. 
tos favorables al operador, los que permitan el acceso a una actividad o su ejercicio; no de ningún acto desfavorable (por ejemplo, los que ordenen el cese en la actividad) ni siquiera de los que denieguen el acceso o ejercicio de la actividad que no impedirán hacerlo en otro lugar.

Es de los actos así acotados de los que se proclama su eficacia nacional lo que, en tanto que provienen de entes infraestatales, comporta conferir a todos esos actos eficacia extraterritorial, eficacia fuera del territorio del ente del que emanan -y eficacia, incluso, en su caso, más allá del ámbito de vigencia de la norma aplicada- hasta cubrir el de toda España ${ }^{26}$.

Y esta eficacia extraterritorial y nacional de tales actos conduce derechamente, y es lo que en verdad se busca y es relevante, a que baste uno sólo de esos actos, el del lugar de origen. $\mathrm{Al}$ operador que ya cuente con ese acto favorable de la autoridad de origen no se le puede exigir ningún otro en ningún lugar de destino de España; es decir, la autoridad de destino -en especial, la de la Comunidad de destino en la que ese operador pretenda vender productos, acceder a una actividad, ejercerla, contratar con la Administración, etc.- no podrá exigir otro medio de intervención, otro control previo, aunque así esté previsto en la normativa que ella misma haya aprobado. Y esto se reitera hasta en tres ocasiones y en los términos más enérgicos en el art. 20: “... sin necesidad de que el operador económico realice ningún trámite adicional o cumpla nuevos requisitos...”; “... sin que pueda exigirse al operador ... otros trámites adicionales"; “... sin que pueda exigirse la realización de ningún trámite adicional...". Es a esto a lo que se alude cuando se habla, como frecuentemente se ha hecho para presentar esta novedad de la LGUM, de "prohibición de doble autorización" o de la regla de "licencia única", expresiones que, aunque gráficas, se quedan cortas para reflejar el verdadero alcance de la regla, como ahora se verá.

Es una regla en sí misma relevante, casi revolucionaria en tanto que supone que una sola autorización -u otro medio de intervención- de una autoridad infraestatal sirve para toda España, no ya sólo cuando la normativa cuyo cumplimiento sea controlado con ella sea estatal, lo que es más fácil de admitir y ya se conocía antes ${ }^{27}$, si-

${ }^{26}$ Vid., así, M. J. ALONSO MAS, "La eficacia de los títulos habilitantes en todo el territorio nacional y la aplicación de la regla del lugar de origen", en la obra colectiva dirigida por la misma Profesora, El nuevo marco jurídico de la unidad de mercado. Comentario a la Ley de Garantía de la Unidad de Mercado, La Ley, Madrid, 2014, pp. 295 a 297.

${ }^{27}$ Con anterioridad a la LGUM ya se conocían supuestos en que la autorización de una Comunidad Autónoma tenía eficacia en toda España e impedía que otra Comunidad exigiera nueva autorización. Así, por ejemplo, para alimentos (STC 87/ 1985) o para productos de metrología (STC 100/1991). Pero se trataba de supuestos en los que, aunque la competencia ejecutiva -y, por 
no también cuando la normativa es autonómica y distinta a la del resto de las Comunidades Autónomas.

Pero, a fuer de exactos, esta regla revolucionaria es sólo el resultado de la proclamación radical de la eficacia nacional de las normas del art. 19. Realmente, si el operador que ya actúa en una Comunidad conforme a las normas de ésta puede ejercer su actividad en otra Comunidad sin cumplir las normas de esta otra, no parece que tenga sentido que esta segunda condicione ese ejercicio a un control previo: o bien comprobaría el cumplimiento de lo mismo que ya ha acreditado ante la autoridad de origen, lo que sería disfuncional y hasta absurdo, o bien pretendería comprobar el cumplimiento de otros requisitos, los establecidos en su propia normativa, lo que no cabe porque, como sabemos, el operador no tiene que cumplir esos requisitos de la normativa del lugar de destino.

Pero ni con todo lo anterior se capta en su plenitud lo realmente consagrado porque no se prohíbe sólo el segundo control sino todo control de este género impuesto por la autoridad de destino aunque en el lugar de origen no se haya establecido ninguno de estos controles. Se deduce esto, más que del art. 20, del art. 19.3. Es allí donde queda claro que "incluso cuando en la normativa del lugar de origen no se exija ... control ... alguno", tampoco lo puede exigir la autoridad de destino aunque su normativa imponga "controles previos". O sea, que no se trata sólo de que no podrá pedirse una segunda autorización (o un segundo control previo) sino ni siquiera una primera: si la autoridad de origen decidió que no es necesario nada para realizar una actividad en su territorio, quien acceda a la actividad en éste la podrá realizar en cualquier parte de España sin ningún control previo. En este caso ni siquiera pueda hablarse de la eficacia nacional o de extraterritorialidad de la autorización o similar,

tanto, la de otorgar o denegar la autorización- era autonómica, la normativa era estatal y, por tanto, todas las autorizaciones autonómicas controlaban lo mismo y reflejaban la superación de idénticos requisitos. Es lo mismo que se ha venido aceptando en Alemania cuando los actos del ente se producen en aplicación del Derecho de la Federación, como explican R. BOCANEGRA SIERRA y J. GARCÍA LUENGO, "Los actos administrativos transnacionales", RAP, n 177 (2008), pp. 2829. Pero allí mismo, explican que, aunque ha habido algún intento doctrinal, se ha rechazado la "eficacia transterritorial de los actos administrativos" cuando no se trata de esa aplicación del Derecho de la Federación. Incluso cuando se trata de actos de eficacia transnacional la justificación suele estar en una previa armonización de la normativa aplicable (ibídem, p. 15). Igualmente C. PADRÓS REIG y J. M. MACÍAS CASTAÑO, "Los instrumentos administrativos de garantía de la unidad de mercado", RAP, n 194 (2014), pp. 126-127, destacan que "la armonización de las exigencias esenciales es un prerrequisito para el funcionamiento del reconocimiento" mutuo. Pero la novedad de la LGUM es imponer todo eso de la manera más extremosa y aun con normativas autonómicas que pueden ser muy distintas entre sí. 
ya que no la hay, sino sencillamente de la eficacia nacional de la normativa que no impone ningún control previo. Todo esto se suma a las ya rigurosas limitaciones impuestas a los controles previos en virtud del principio de necesidad. Recuérdese que éste sólo admite que las Comunidades Autónomas sometan una actividad económica a autorización por algunas pocas razones imperiosas de interés general especialmente valiosas. Hay que presuponer, pues, que si la normativa de destino exige una autorización es porque así lo requieren ineludiblemente esas razones. Pero ni aun así se admitirá que se exija tal autorización a quien proviene de otro lugar en que no hubo de superar ningún control previo.

Y todavía hay más porque lo que se excluyen no son sólo los controles previos de la autoridad de destino sino, como machaconamente reitera el art. 20 LGUM, cualquier "trámite adicional". Así que no cabe imponerle al operador ni un acto de la autoridad de destino por el que reconozca la eficacia del acto foráneo y ni tan siquiera un deber de mera comunicación puramente informativa para que la autoridad de destino sepa que en su territorio hay un nuevo operador, una comunicación de las que sí permite el principio de necesidad (arg. art. 17.3 LGUM) pero que en lo que ahora nos ocupa queda prohibida por este tajante principio de eficacia nacional. Si es que la autoridad de destino quiere esa información, habrá de recabarla de la de origen: para ello, los arts. 22 a 25 LGUM establecen medios jurídicos y técnicos para que fluya esa información. El problema es que podrá suceder que, en realidad, la autoridad de origen no tenga esa información porque no haya exigido a su operador ningún control previo para acceder a la actividad ni, desde luego, para pasar a operar en otro lugar ${ }^{28}$.

Visto todo esto, se comprende que lo consagrado es mucho más que la eficacia nacional y extraterritorial de ciertos actos de entidades infraestatales: significa que cada una de ellas, al abrir las puertas en su propio territorio -incluso, si quiere, sin ningún control previo-, las abre también de par en par para todo el mercado nacional sin que en ningún lugar se pueda exigir nada más. E incluso cabe que el mismo operador vaya llamando sucesivamente a las distintas puertas -las de cada una de las diecisiete Comunidades Autónomas- sin que el que se le cierren en una impida que se le abran en otra, porque la eficacia nacional es sólo de los actos favorables, no de los denegatorios; y por esa puerta accederá incluso a la Comunidad que expresamente le negó la entrada.

${ }^{28}$ En relación con los Colegios Profesionales, cuando se suprimió hasta la posibilidad de exigir una comunicación al Colegio de destino, el art. 3.3 de la Ley de Colegios Profesionales lo decía expresamente: "En los supuestos de ejercicio profesional en territorio distinto al de la colegiación, a los efectos de ejercer las competencias de ordenación y potestad disciplinaria..., los Colegios deberán utilizar los oportunos mecanismos de comunicación y los sistemas de cooperación administrativa entre autoridades ...". 
B) Excepciones a la prohibición del control de la autoridad de destino

Las únicas tres excepciones a la prohibición de controles por parte de la autoridad de destino son las contenidas en el art. 20.4 LGUM. En parte, no son verdaderas excepciones sino una delimitación obvia de la regla ${ }^{29}$ : lo que la autoridad de origen consintió para su territorio y a lo único que, por tanto, se puede dar eficacia nacional es al acceso del operador a la actividad misma, a su ejercicio, no a otra cosa; y estas excepciones se refieren a otra cosa.

No se consintió al operador, claro está, que utilice un espacio demanial sobre el que evidentemente no puede disponer la autoridad de origen, no ya porque ese espacio esté fuera de su territorio sino porque tendrá otra Administración titular que es la única que puede decidir sobre sus aprovechamientos privativos o especiales. Así que la excepción enunciada por el art. 20.4 LGUM, según la cual el principio de eficacia nacional no se aplicará "a los actos administrativos relacionados con la ocupación de un determinado dominio público" y que, por tanto, permite exigir en el lugar de destino concesiones o autorizaciones demaniales, no es siquiera una verdadera excepción sino una obviedad. Obviedad, con todo, que no huelga, porque el hecho de que se hable de autorizaciones puede generar confusión, como ya lo hizo al trasponerse la Directiva de Servicios.

Algo similar puede decirse de la excepción relativa a las "autorizaciones, declaraciones responsables y comunicaciones vinculadas a una concreta instalación o infraestructura física". Sobre esa concreta instalación o infraestructura en el lugar de destino no se pronunció ni se pudo pronunciar la autoridad de origen por lo que, no es que se niegue a su actuación eficacia fuera de su territorio, sino que no se le da para aquello sobre lo que nada dijo. La autoridad de origen sólo permitió acceder y ejercer una actividad económica, no construir un edificio o hacer emisiones a la atmósfera o al suelo o alterar bienes del patrimonio histórico... y todo ello, como no podría ser de otra forma, explica que la autoridad de destino -que en este caso es más bien simplemente la autoridad del lugar en que se sitúa tal realidad física- someta esas actuaciones a autorización, comunicación o declaración responsable. Con ello no se está negando ni un ápice de la eficacia extraterritorial a la decisión de la autoridad de origen sino ajustando tal eficacia a su verdadero contenido. La LGUM, que trata de evitar cualquier escape o tentación y parece resabiada de antemano, tiene la cautela de aclarar que ese control sí permitido a la autoridad de destino no puede aprovecharse para exigir y

${ }^{29}$ En parecido sentido G. FERNÁNDEZ FARRERES, "Unidad de mercado y libertades...", cit., p. 142. 
controlar requisitos no "ligados específicamente a la instalación o infraestructura". Sirviéndonos de la clásica distinción entre autorizaciones reales, personales y mixtas, cabe decir que lo que la ley quiere es que esas autorizaciones de la autoridad de destino sean puramente reales sin convertirse en mixtas controlando también aspectos subjetivos del operador. Para estos subsiste intacta la prohibición de control de destino sin que la autorización de la infraestructura pueda servir de subterfugio para burlarla. Pese a todo, el alcance de esta excepción puede resultar problemático. Sin duda consiente autorizaciones urbanísticas, ambientales y similares. Pero es más discutible si permitirá controlar los requisitos físicos impuestos por la legislación sectorial de la actividad aprobada por la autoridad de destino (por ejemplo, los específicos de los gimnasios, las academias, las residencias de la tercera edad...) o si ello chocaría con la libertad "mediante establecimiento físico" que se proclama en el art. 19.1.

La última excepción se refiere a los casos en los que en el lugar de destino esté limitado el número de operadores "en función de la existencia de servicios públicos sometidos a tarifas reguladas". Aquí sí que hay una verdadera excepción porque al operador que ya actúa en un lugar se le impide el ejercicio de esa misma actividad en otro: aunque pueda realizar tal actividad económica en el lugar de origen (porque allí es libre o porque cuenta con autorización o concesión de servicio público), sí podrá exigírsele un control o incluso un título específico (una autorización, una habilitación...) en el lugar de destino, título otorgado por la autoridad de destino que, desde luego, podrá denegarlo por diversas razones, entre ellas por el simple hecho de que ya hay operadores suficientes. Es, eso sí, una excepción lógica, inevitable. Sin ella se estaría negando toda posibilidad de declarar una actividad servicio público o, al menos, se estarían mermando parte de sus consecuencias posibles. En particular, concuerda con la posibilidad de reservar al sector público servicios esenciales que consagra el art. 128.2 CE, posibilidad que en general se entiende conferida no sólo al Estado sino a las Comunidades Autónomas en materias de su competencia. Si esto se acepta, hay que entender que esta excepción del art. 20.4 LGUM rige no sólo en los casos de servicios públicos declarados como tales por el Estado y regulados por él sino también en los que declarasen y regulasen las Comunidades Autónomas que de esa forma sí podrían alzar una barrera a la eficacia nacional de los actos de las otras. Así las cosas, lo que más bien sorprende de esta excepción es la forma en la que se describe (limitación del número de operadores y tarifas reguladas) pues bien podría haber bastado aludir a que en el lugar de destino la actividad esté configurada como servicio público o reservada al sector público, aunque con posibilidad de gestión indirecta mediante sujetos privados. Quizás la redacción obedezca al deseo de incluir en la excepción los taxis que no son exactamente servicio público sino lo que tradicionalmente se denominaba un servicio público virtual o impropio.

Se comprende con todo, incluso más allá de estas tres limitadas excepciones, que subsiste, aunque mucho más reducidamente, la posibilidad de concurrencia de autori- 
zaciones: pese al principio de necesidad es posible que en el lugar de origen haya que obtener dos o más autorizaciones para una actividad si se dan varias de las pocas razones imperiosas de interés general que las legitiman y si se establece que los correspondientes requisitos se controlen mediante diversas autorizaciones (por ejemplo, porque una corresponda a la Administración autonómica y otra a la local o, incluso, porque subsista una autorización de la Administración del Estado); pese al principio de necesidad unido al de eficacia nacional, también caben excepcionalmente algunas autorizaciones en destino. Así que, en suma, es posible, como decíamos, que sigan dándose supuestos de concurrencia de autorizaciones. Lo que sí quedará asegurado es que ninguna de esas autorizaciones controle lo que ya está cubierto por las otras, aspiración que ya latía en el art. 84 bis.3 de la Ley Reguladora de las Bases del Régimen Local.

\section{Efectos del principio de eficacia nacional; en particular, efectos sobre las competencias normativas autonómicas y peligro de la nivelación a la baja}

Evidentemente el primer efecto del principio radical de eficacia nacional acogido por la LGUM -en realidad, según se ha explicado, de la suma de un extremoso reconocimiento mutuo y predominio de la autoridad de origen- es el de lograr en grado máximo la libre circulación y, en suma, la unidad de mercado. Pero conviene detenerse en lo que podríamos llamar, como en las medicinas, sus efectos secundarios.

El principio de eficacia nacional propicia de inmediato, para empezar, una cierta desigualdad entre los operadores económicos según su lugar de origen, una desigualdad en sus condiciones de acceso y en los consiguientes costes pese a la cual habrán de concurrir y competir en el mismo mercado y por una misma demanda ${ }^{30}$. Se

\footnotetext{
${ }^{30}$ Ya lo destacó Informe del CGPJ sobre el anteproyecto: la ley "puede dar lugar a situaciones de desigualdad material entre operadores económicos que realicen una misma actividad en un mismo territorio", p. 52. Y en ello ha insistido la doctrina. Vid. G. FERNÁNDEZ FARRERES, "Unidad de mercado y libertades...", cit., p. 140; M. J. ALONSO MAS, "La eficacia de los títulos...", cit., pp. 303 y 305, que habla de un "riesgo de discriminación inversa". En la situación anterior, la diversidad normativa entre Comunidades Autónomas propiciaba la posibilidad de que quienes operasen en dos Comunidades Autónomas estuvieran sometidos a condiciones de acceso distintas. Pero si, aunque con diferente lugar de origen, acaban por operar en la misma Comunidad, quedaban sujetos a idénticas condiciones, las impuestas por esa Comunidad, que no podía hacer distingos (art. 139.1 CE). Por tanto, concurrían en esa Comunidad en igualdad. Sólo se producían desigualdades en su lucha competitiva en la medida en que los consumidores, usuarios y potenciales clientes de todo género pudieran desplazarse de una Comunidad a otra o, incluso sin desplazamiento, pudieran adquirir bienes y servicios en otra Comunidad. En cambio, ahora, con la LGUM, competirán en la misma Comunidad operadores que pueden haber tenido condiciones de acceso muy diversas según su lugar de origen.
} 
verá favorecido aquél que acceda a la actividad en el lugar de España en que menos requisitos se exijan. Sería, cabría decir, una especie de versión española del célebre "fontanero polaco" que en su momento se convirtió en referencia permanente en los debates sobre la Directiva de Servicios; versión, desde luego, mucho más moderada porque las diferencias normativas entre unas y otras partes del territorio nacional siempre serán muy inferiores a la que existe entre los distintos Estado de la Unión Europea. Las muchas competencias estatales sobre materias capitales (v. gr., sobre Derecho del trabajo, mercantil, financiero, seguridad social) hacen que las diferencias que puedan existir entre las diversas Comunidades Autónomas sean menores y menos relevantes que las que puede haber entre, por ejemplo, Polonia y Suecia. Pero, aun reconociéndolo así, sí que, aunque con menores márgenes, se origina una cierta diferencia entre competidores.

Casi consustancial a lo anterior será la tendencia de los operadores económicos a trasladarse a la Comunidad Autónoma cuya normativa sea menos exigente. Puesto que con su acceso a la actividad en cualquier lugar del territorio nacional se asegurarán igual mercado, el de toda España, propenderán con toda lógica a hacerlo allí donde menos requisitos se les exijan y huirán de cualquier otro en que se les impongan condiciones más severas lo que, además, comportará de ordinario incurrir en mayores costes. O sea que se potencia la conocida "deslocalización” a la búsqueda de la legislación más laxa, menos estricta ${ }^{31}$. Quizás pueda decirse, para describirlo de forma idílica, que el operador irá a la búsqueda de la regulación menos formalista, menos burocrática, más ágil... pero también será a veces -incluso muchas veces- la menos protectora de los intereses generales concernidos.

Seguramente lo anterior -desigualdad y deslocalización a la búsqueda de la regulación menos gravosa- no sean más que efectos transitorios. Pero efectos transitorios, cabe temer, que no presagian nada bueno y que a la postre, más pronto que tarde, conducirán a restablecer la igualdad y a frenar la deslocalización pero gracias a una uniformidad regulatoria poco exigente. Para comprobarlo, analicemos ahora sus efectos sobre las competencias de los entes territoriales, destacadamente sobre las de las Comunidades Autónomas, que es lo que aquí prioritariamente nos incumbe.

Con este drástico principio de eficacia nacional las Comunidades Autónomas no pierden ninguna competencia. Para aquello que la tuvieran, podrán seguir aproban-

31 A este respecto M. J. ALONSO MAS, "La eficacia de los títulos...", cit., pp. 304-305, recuerda que según la STC 96/2002, "toda medida que ... fomente el traslado de empresas incidirá lógicamente en la libertad de circulación y, por tanto, en la libertad de empresa", y ello le lleva a afirmar que "aunque resulte una paradoja, la aplicación a rajatabla del criterio de la normativa de origen puede incidir de forma negativa sobre la libre circulación”. 
do las normas correspondientes sobre acceso a cualquier actividad económica. Más todavía, no sólo conservan íntegra su titularidad sino que tampoco encuentran en este principio ningún nuevo condicionante o límite material a su ejercicio; es decir, que no sólo podrán seguir aprobando esas normas sino que el principio de eficacia nacional no merma su posibilidad de hacerlo en el sentido que quieran y, por tanto, en el de optar por garantizar los intereses generales en el nivel y en la forma que quieran; un nivel tan elevado y una forma tan rigurosa como estimen conveniente. Competencia normativa y libertad para ejercerla que queda incólume incluso para someter una actividad a la necesidad de autorización u otro control previo. Es el principio de necesidad el que sí le impone esos límites. Pero con el de eficacia nacional que ahora analizamos ni pierden competencias ni libertad en su ejercicio. Hasta podría decirse en sentido contrario que ganan algo porque, con la misma competencia, al ejercerla en un sentido o en otro, influirán sin freno, más allá de su territorio, en toda España. O sea, que todas deciden la forma y el grado de protección de los intereses generales en el resto de Comunidades. Así, si la Rioja tiene competencia para regular, por ejemplo, los requisitos que permitan ejercer de agente de la propiedad inmobiliaria o de gestor administrativo, podrá seguir aprobando la correspondiente normativa con total libertad y, además, al hacerlo estará determinando no sólo los necesarios para acceder por primera vez a tales actividades en su territorio sino para después ejercerlas en toda España, incluso mediante establecimiento físico.

Pero si formalmente es así, materialmente las cosas serán muy distintas porque esa regulación de una Comunidad Autónoma que exija elevados requisitos resultará inútil y hasta contraproducente para los intereses generales que le conciernen. En primer lugar, será inútil porque en su territorio también podrán vender y actuar, aunque no los cumplan, los operadores establecidos en otras Comunidades Autónomas que impongan menos requisitos o ninguno; o sea, que no conseguirá ni remotamente garantizar a sus ciudadanos el nivel de protección que pretendía con su normativa. Sólo logrará someter a los operadores localizados en su territorio, incluso cuando vendan todos sus productos y servicios en otros territorios. Volviendo a nuestro ejemplo, la Comunidad riojana podrá conseguir que los agentes de la propiedad inmobiliaria que accedan a tal actividad en la Rioja sean los mejor preparados de España, los que ofrezcan mejor asesoramiento, los que además hayan de constituir mayores garantías..., pero con ello no impedirá que ejerzan en su propio territorio los que hayan accedido a esa misma actividad en cualquier otra Comunidad Autónoma sin que se les exija ninguno de esos requisitos. Cada Comunidad Autónoma queda a merced de lo que se decida en las restantes. Y, en segundo lugar, será incluso contraproducente porque lo que sí conseguirá es espantar a los operadores económicos que, como antes se dijo, buscarán y preferirán establecerse en la Comunidad Autónoma más cómoda y menos costosa con la que se asegurarán por igual el mercado nacional completo, incluido el de esa Comunidad Autónoma tan escrupulosa. Volviendo de nuevo al ejemplo, incluso para ejercer en la Rioja, mejor 
elegir como lugar y autoridad de origen otra Comunidad Autónoma. Por tanto, todo induce a que esa Comunidad rebaje sus exigencias con lo que tendrá satisfechos a sus operadores, atraerá a otros y no perjudicará más a sus consumidores y usuarios. Naturalmente, esto tendrá efectos en cadena y cada Comunidad Autónoma irá sucesivamente rebajando sus exigencias a medida que lo vayan haciendo las demás, todas en una carrera frenética hacia la desregulación, carrera en la que triunfará la que cuanto antes acabe por no exigir nada ${ }^{32}$. Puestos a alabar la competencia, lo que nos encontramos es con la competencia entre reguladores que rivalizarán por ofrecer la puerta más grande y más fácil al mismo mercado. Así, el peligro de la "nivelación por abajo", del que tantas veces se ha hablado en la Unión Europea, encuentra aquí un nuevo campo, pero con una diferencia: en el Derecho europeo el Estado de destino sí puede oponer su normativa indistintamente aplicable a sus nacionales y a los operadores de otros Estados miembros cuando demuestre que ello responde a razones imperiosas de interés general o exigencias imperativas, incluso porque ha optado por proteger el interés general en un grado superior al del Estado de origen; sin embargo, una Comunidad Autónoma no podrá alegar nunca ninguna razón para exigir los requisitos de su normativa ni aunque pruebe cumplidamente que la normativa de la Comunidad de origen, acaso por esa tendencia a la baja que la LGUM propicia, no es suficiente para garantizar en el nivel adecuado el interés general pues, recuérdese, la LGUM no admite a este respecto excepciones por ninguna razón.

Desde luego, si la LGUM busca como un bien la desregulación, puede decirse que por esta vía la estimula con inusitado vigor. Con su principio de necesidad la impone directamente en gran medida; con su principio de eficacia nacional la fomenta más allá de lo que la impone aquél. No puede negársele su congruencia y su habilidad: logra reforzar la unidad de mercado con la máxima desregulación o liberalización de las actividades económicas; o, quizás, logra esto con el pretexto de aquello.

A la larga, si el panorama legislativo que ofrezca la suma de las diversas normativas autonómicas en su pendiente desreguladora se juzga insuficiente para asegurar un adecuado nivel de protección de determinado interés público, la solución habrá de encontrarse en una regulación común, que deberá ser estatal, salvo que la suministren las instituciones europeas. El fenómeno no es nuevo. No, desde luego, en la Unión Europea, donde Reglamentos y Directivas, pese a que allí el reconocimiento mutuo admite muchas más excepciones, se han convertido en la forma de garantizar

32 Vid. , J. TORNOS MAS, "La Ley 20/2013, de Garantía de la Unidad de Mercado: una reforma discutible", cit., que habló de "dumping regulatorio". 
una elevada protección de los consumidores o del medio ambiente, por sólo citar dos materias especialmente relevantes. Ahora, con este principio de eficacia nacional consagrado en la LGUM, se podrá reproducir a escala y con matices el mismo proceso: en la medida en que el Estado pueda invocar algún título de competencias, será él quien pueda imponer un mínimo común normativo que servirá además como mínima protección del interés general tutelado, como el mínimo que frenará esa deriva hacia la protección a la baja en la que se sume a las Comunidades Autónomas. Será entonces normal que se reclame esa regulación estatal que, en este nuevo contexto, será recibida con júbilo como la salvación de los intereses generales en peligro. Dicho de otra forma, el sistema de la LGUM tiene como efecto remoto una potenciación de la legislación estatal y un acicate para que el Estado se sirva de todos sus títulos competenciales (incluido el de las leyes de armonización, si no hay otro) con la finalidad de penetrar en todas las materias cuyo dominio corresponde, en principio, a las Comunidades Autónomas y salvar así lo que éstas, por su permeabilidad a las regulaciones de las demás y por su lucha en la captación de operadores, ya no podrán salvaguardar por sí solas.

\section{La correlativa distribución de las competencias de su- pervisión entre las autoridades de origen y de destino: el desarme de las autoridades de destino}

Conforme a lo anterior quedan delimitadas las competencias de las autoridades de origen y de destino para determinar las condiciones de acceso al mercado de productos y servicios, para decidir si se sujetan a algún control previo y para hacer en concreto tal control en cada caso. $\mathrm{Y}$ ya hemos visto el predominio casi absoluto que a este respecto otorga la LGUM a la autoridad de origen y la correlativa postergación de la autoridad de destino. Pero queda por resolver la situación posterior y ya puramente ejecutiva respecto a la "supervisión" los concretos bienes y servicios que ya se están ofertando en el mercado.

En concreto, hay dos géneros de cuestiones pendientes. Por un lado, queda por resolver qué entidad -la de origen o la de destino- será la competente para vigilar posteriormente que cada específico operador ya establecido y cada uno de los bienes y servicios que ya oferte en un concreto territorio cumple efectivamente las condiciones a que están sometidos por la legislación que le sea aplicable, incluida en su caso la superación de los controles que se les impuso. Por otro lado, queda por resolver qué entidad, caso de que se detecte que un operador o uno de sus productos o servicios no las cumple, será la competente para adoptar las medidas de reacción, ya sean las necesarias para restablecer la legalidad (ordenar el cierre de un establecimiento, la retirada del mercado un producto o un servicio, la modificación del producto o del servicio, etc.) ya sean las sancionadoras que procedan. 
El problema se suscita, en particular, cada vez que el asunto supere el ámbito de una Comunidad Autónoma: cuando el operador esté instalado en una pero venda productos u oferte servicios en otra o en otras o en todas, lo que, claro está, no es nada excepcional sino lo más normal. O sea, cada vez que no coincidan Comunidad de origen y de destino.

Este género de problemas ante asuntos supraautonómicos, desde luego, existían antes de la LGUM y se plantean incluso cuando toda la competencia legislativa es estatal si la ejecución es autonómica. Pero se hacen más relevantes y enrevesados cuando las Comunidades tienen todas o parte de las competencias legislativas porque entonces ya no se tratará sólo de saber qué Administración autonómica será la competente para inspeccionar, imponer medidas de restablecimiento de la legalidad y sancionar sino también conforme a qué normativa lo hará. Sólo en algunos sectores el legislador estatal ha ofrecido soluciones más o menos completas a este tipo de situaciones. Pero en general es un problema no resuelto.

La LGUM tiene el acierto de abordarlo. Lo hace su art. 21. Y es oportuno traerlo aquí no sólo por su interés en sí mismo sino porque introduce reglas complementarias a las que venimos analizando y concordantes con ellas. Pero debe notarse que las reglas que establece son de aplicación ante supuestos supraautonómicos en todos los casos en que la "competencia de supervisión y control no sea estatal". Por tanto, son de aplicación cuando se supervise el cumplimiento de normas estatales y cuando se supervise el de normas autonómicas. Así, ese art. 21 sirve por igual para determinar la competencia de supervisión, por ejemplo, en materia de metrología, en la que la legislación es exclusivamente estatal, y en materia de turismo, de competencia legislativa íntegramente autonómica. O sea, que este art. 21 LGUM tiene un radio de aplicación bastante más amplio que el del principio de eficacia nacional de las normativas autonómicas. También es un acierto que la LGUM haya afrontado esa otra situación en la que las normas son estatales pero las competencias administrativas para controlar su cumplimiento y reaccionar ante su transgresión son de las diversas Comunidades Autónomas porque también a este respecto se vienen suscitando problemas.

El art. 21 LGUM alude a esas competencias de vigilancia del cumplimiento y de reacción ante la ilegalidad como competencias de "supervisión". Aunque el término "supervisión" se utilice hoy con frecuencia no está perfectamente acotado ni es fácil delimitarlo con precisión. En un momento, como hemos visto, el precepto habla de "supervisión y control"; después, ante la eventual detección de incumplimientos, se refiere a la adopción de las "medidas oportunas, incluida las sancionadoras". Ante ello, parece que puede aceptarse que con ese término de supervisión el art. 21 inclu- 
ye tanto la inspección como todas las medidas de reacción ante eventuales incumplimientos, incluidas las sancionadoras ${ }^{33}$.

Ese art. 21 LGUM ante esos supuestos supraautonómicos no asume la solución de confiar la supervisión a la Administración del Estado (como se ha hecho, por ejemplo, en materia de defensa de la competencia o de denominaciones de origen). Así que, con acierto -pues esa solución de atribuir la competencia al Estado cada vez que haya supraterrirtorialidad no está justificada ni resulta funcional- tampoco a este respecto la LGUM aumenta las competencias estatales ni priva de ninguna a las Comunidades Autónomas. Lo que hace es distinto: partiendo de que la competencia es autonómica y de que sigue siéndolo en los supuestos de supraterritorialidad, lo que hace es establecer criterios para determinar cuál de las Comunidades Autónomas implicadas es competente.

Con esas premisas, la ley distingue una vez más entre condiciones para el acceso a la actividad y condiciones del ejercicio de la actividad. Aquéllas, según el art. 21.2.a), las controlará la autoridad de origen; éstas, según el art. 21.2.b), la autoridad de destino. Por tanto, la LGUM soluciona la cuestión de forma concordante con lo que ella misma ha establecido para la fase anterior: como parte de que las condiciones de acceso las determina la autoridad de origen, a esta misma confiere las competencias de supervisión de tales condiciones; como parte de que las condiciones de ejercicio las determina para su territorio la autoridad de destino, a ésta misma otorga las competencias de supervisión de esas otras condiciones. O sea, hay concordancia entre, de un lado, la competencia normativa y de control previo y, de otro lado, la de supervisión a posteriori, de manera que cada entidad -en suma, cada Comunidad Autónoma- supervisará el cumplimiento de aquellas condiciones que ella misma ha establecido. Así, volviendo al ejemplo simple antes usado, la empresa de tintorería navarra que presta servicios con establecimiento o sin él en Aragón será supervisada en sus condiciones de acceso por la Comunidad Foral y en el ejercicio de su actividad en Aragón por la Diputación General.

La misma Ley es consciente de la insuficiencia de su distinción, que sólo es idónea para los servicios, e introduce una regla específica para los productos en el art. 21.2.c): "Las autoridades del lugar de fabricación serán las competentes para el con-

33 En contra, acoge una interpretación más restrictiva, que prácticamente identifica la supervisión de la que habla este precepto sólo con la inspección, J. OCHOA MONZÓ, "La articulación de la supervisión de los operadores económicos, en M. J. ALONSO MAS (Dir.), El nuevo marco jurídico de la unidad de mercado. Comentario a la Ley de Garantía de la Unidad de Mercado, La Ley, Madrid, 2014, p. 408. 
trol del cumplimiento de la normativa relacionada con la producción y los requisitos del producto para su uso y consumo". Ya anunciamos que la Ley se aparta aquí de su clasificación entre autoridades de origen y de destino, e introduce a la autoridad del lugar de fabricación. Así, será la Comunidad Autónoma en la que se encuentra una fábrica la competente, no ya para controlar que esa fábrica cumple los requisitos legales (de construcción, de mantenimiento, de higiene, de personal, de maquinaria, etc.), sino también que los productos que elabora cumplen los "requisitos para su uso y consumo". Por tanto, si una fábrica situada en Galicia vende sus productos en Cataluña, según este art. 21.2.c), sólo las autoridades de la Xunta serán competentes para controlar que esos productos son conformes con la legalidad. Y si el mismo operador tiene otra fábrica en Asturias que produce exactamente los mismos productos que la gallega y que comercializa también en Cataluña, serán las autoridades del Principado las competentes. A este respecto de la fabricación y de los productos no hay ningún reconocimiento de competencias supervisoras en favor de las autoridades de destino.

Estas reglas se completan con la del apartado 3 del mismo art. 21: si la autoridad de destino detecta el incumplimiento de requisitos de acceso a la actividad o de normas de producción o de requisitos de los productos (lo que parece que sólo puede ser consecuencia de un "hallazgo casual" puesto que en principio no es objeto de su supervisión) no debe adoptar ninguna medida sino comunicarlo a la autoridad de origen (o la autoridad del lugar de fabricación, aunque el precepto no lo dice) "para que ésta adopte las medidas oportunas, incluidas las sancionadoras que correspondan".

Aun reconociendo el mérito de abordar esta espinosa cuestión, la concreta solución del art. 21 LGUM es más discutible, especialmente en su proyección sobre productos. Y más todavía para los casos en los que la normativa cuyo cumplimiento ha de ser supervisado es estatal, supuesto éste que, como se ha explicado, también está comprendido en el ámbito de aplicación del art. 21 y que es el más frecuente en lo que se refiere a productos. En esta hipótesis no se da la concordancia que pretende la Ley: si lo que quiere es que cada Comunidad Autónoma supervise sólo la observancia de las normas que ella misma ha establecido, cuando se trata de supervisar el cumplimiento de la normativa estatal ya no se da aquel presupuesto. Y, sin embargo, en todo caso confiere el mismo predominio a la Comunidad de origen, predominio injustificado y de muy dudoso acierto.

Para empezar, es inconveniente para la adecuada protección de los valores públicos porque confiere las competencias de control y de reacción a la Comunidad Autónoma que no sufre la lesión y que, en principio, tiene menos interés en el restablecimiento de la legalidad y en la represión de las infracciones. Si la fábrica situada en Madrid vende todos sus productos ilegales en Murcia, será la Administración de esta región la prioritariamente interesada en tomar medidas mientras que la Comunidad 
madrileña sólo sentirá próxima a su empresa y más remotamente a los consumidores perjudicados. Pero la LGUM sólo da competencias a la Administración del lugar de origen no a la de destino que es en la que se sufre más directamente la lesión del interés general concernido. Además, se aleja la decisión administrativa de los ciudadanos lesionados por la ilegalidad que, claro está, se encuentran en el lugar de destino.

Es también de difícil aplicación práctica. Así, por ejemplo, si se trata de inspeccionar que cumplen la legalidad ciertos productos comercializados en Andalucía -incluso, supongamos, exclusivamente en Andalucía-, quienes tienen facilidad para hacerlo (recoger muestras, someterlas a análisis o ensayos...) son las autoridades de la Junta de Andalucía, aunque la fábrica esté en Valladolid, donde acaso ni siquiera queden restos del lote cuestionado. Además, sin duda serán las mismas autoridades andaluzas las competentes para inspeccionar los productos comercializados allí cuando son fabricados en Francia o Alemania, y es complicar las cosas mantener que sí que pueden inspeccionar estos pero no los de Valladolid. Pero es eso lo que consagra la LGUM. Lo mismo hay que decir sobre la adopción de las medidas de reacción: si se trata de acordar la retirada del mercado vasco de juguetes fabricados en la Comunidad Valenciana, tal medida habrá de ejecutarse en el País Vasco y es complicar innecesariamente la situación establecer que sólo puedan adoptar tal medida las autoridades valencianas, que es lo que consagra la LGUM, solución enrevesada que, además, exige aceptar también la eficacia extraterritorial de esa decisión de la autoridad de origen que habrá de ejecutarse íntegramente en la Comunidad de destino, extraterritorialidad, por cierto, no establecida en la LGUM que, con su visión siempre favorable a las empresas, sólo consagra la eficacia nacional de los actos favorables pero no de los de gravamen.

Por otro lado, esa extraña solución de la LGUM no concuerda con la establecida ya por otras normas. Por ejemplo, por el Texto Refundido de la Ley para la Defensa de los Consumidores y Usuarios y el RD 1801/2003, sobre seguridad de los productos. Nadie discute que una Comunidad Autónoma puede someter a análisis y ensayos los productos que se venden en su territorio, aunque se produzcan en el de otra, ni nadie osa poner en cuestión que, si detecta que son ilegales y peligrosos, acuerde las medidas necesarias para restablecer las condiciones de seguridad y salubridad, por ejemplo, la retirada del mercado. Eso se viene aplicando con normalidad y sin grandes problemas, aunque completado con sistemas de información, coordinación y colaboración entre todas las autoridades implicadas ${ }^{34}$. Hasta podría soste-

34 Sólo hay una previsión para situaciones de "carácter excepcional" y de "extrema gravedad" de peligro para "la salud y seguridad de los consumidores y usuarios en más de una Comunidad Autónoma": para tal supuesto se permite que el Gobierno constituya un órgano extraordinario en el 
nerse que este art. 21 LGUM tampoco concuerda bien con otros preceptos de la misma Ley. Por ejemplo, con el art. 24.2, que dispone que la autoridad de destino podrá requerir a la autoridad de origen información para comprobar que el operador se encuentra legalmente establecido o para instarle la práctica de comprobaciones, inspecciones e investigaciones respeto a los operadores que, localizados en el territorio de ésta, operen en el de aquélla. Si esto es así, es que no le son indiferentes las condiciones de acceso a la actividad ni las de producción ni, menos aún, la de los productos.

La solución del art. 21 LGUM, además de inconveniente, de difícil aplicación práctica e incoherente con el resto del ordenamiento, deja a la Comunidad de destino, si no inerme, sí muy mermada y en gran medida a expensas de la diligencia y buena voluntad de la de origen de la que dependerá que se hagan efectivos controles y que se adopten medidas de restablecimiento de la legalidad y sancionadoras respecto a conductas que acaban repercutiendo directamente sobre lo que se ofrece en su territorio y a su población. Y ello sin establecer ningún sistema coactivo para vencer la pasividad de la autoridad de origen ${ }^{35}$. Aun más indefensos quedan los consumidores y usuarios del lugar de destino pues, si siempre les es difícil combatir la inactividad inspectora y sancionadora de sus propias autoridades, ahora tendrán que intentarlo frente a las de otras Comunidades Autónomas, las de origen, cuyo interés por controlar y reprimir a sus empresas para tutelar los derechos de los ciudadanos de otra Comunidad no cabe presumir muy elevado.

Seguramente la LGUM no pretendía una conclusión como la que hemos expuesto. Y quizás, hasta quepa alguna interpretación correctora que modere los perversos efectos de su art. 21. Acaso haya ya algo de esto en uno de esos Acuerdos de

que "se integrarán y participarán activamente las Comunidades Autónomas afectadas, que asumirá las facultades administrativas..." (art. 16 del Texto Refundido de Defensa de los Consumidores). Pero este mecanismo excepcional y por ahora inédito confirma la regla de que las autoridades autonómicas de destino son las que normalmente inspeccionan todos los productos y servicios que se ofertan en su territorio y las que adoptan todas las medidas para restablecer la salud y seguridad de los consumidores.

${ }^{35}$ En la Directiva de Servicios -además de que no merma de esta forma las competencias de supervisión de los Estados de destino ni es aplicable a productos- sí hay una previsión de este género en su art. 28.8: "Los Estados miembros comunicarán a la Comisión información sobre los casos en que otros Estados miembros incumplen su obligación de asistencia recíproca. En caso necesario, la Comisión adoptará medidas apropiadas, incluido el procedimiento establecido en el art. 226 del Tratado, para garantizar que los Estados miembros de que se trate cumplan sus obligación de asistencia recíproca...". 
Comisiones Bilaterales de los que hablábamos antes ${ }^{36}$. Como mínimo, introduce factores que aumentarán la confusión y que bien podrá ser aprovechada por los operadores para poner trabas a las inspecciones y para alegar la incompetencia de las autoridades de destino al imponer medidas de restablecimiento de la legalidad y sanciones.

Así, en suma, en un aspecto necesitado efectivamente de solución como es el de las competencias de supervisión en asuntos supraautonómicos y que la LGUM tiene el acierto de afrontar, su solución es más bien perturbadora. En realidad lo es porque parte de un planteamiento equivocado y simplista. Para estas otras cuestiones la unidad de mercado y los instrumentos para garantizarla no aportan de ninguna forma las soluciones sino el problema: el problema está en armonizar, de una parte, un mercado unitario con, de otra, una fragmentación del sistema administrativo. Y para abordarlo correctamente el camino no consiste en reforzar el papel de las autoridades de origen en detrimento de las de destino sino, exactamente al contrario, reforzar el de éstas y dar a sus decisiones (ahora, precisamente, a sus actos de gravamen) eficacia extraterritorial y nacional. O sea, el correlativo oportuno a la eficacia nacional de las decisiones favorables de las autoridades de origen en cuanto al acceso al mercado consiste en dar esa misma eficacia a los actos perjudiciales de las autoridades de destino. Y es a ello, además, a lo que debe conducir un cabal entendimiento del principio de confianza mutua de las diversas autoridades: confianza para lo bueno, sí, pero confianza para lo malo, también; confianza de las autoridades de destino en las de origen, sí, pero confianza de las de origen en las de destino, también. Y tan importante para la unidad de mercado es que circulen con pocas trabas los operadores, servicios y productos legales como que no lo hagan los ilegales. No es ocasión de desarrollar aquí todos los aspectos a los que debe conducir este otro planteamiento: delimitación territorial de las potestades inspectoras, reconocimiento mutuo de las actuaciones inspectoras de una Administración para la adopción de acuerdos por otra, determinación del lugar en que se entienda cometida una infracción cuando la acción se localiza en varios o sus efectos se producen en otros distintos, criterios de preferencia en casos de concurrencia de varias Administraciones competentes, eficacia extraterritorial de las los actos de restablecimiento de la legalidad y de

36 En concreto, en el pactado con Galicia, la discrepancia se resuelve afirmando que "el art. 21.2.c) y 3 hacen referencia exclusivamente a la capacidad de supervisión en origen y respecto a los requisitos de acceso, sin afectar a los requisitos de ejercicio que estén establecidos en cada caso". No es mucho más clara esta interpretación que los preceptos interpretados salvo en su referencia a la "supervisión en origen" y, respecto a esto, si realmente lo que se quería decir es sólo que la "supervisión en origen" corresponde a la autoridad de origen o a las autoridades del lugar de fabricación, resulta una obviedad que nunca se ha discutido. 
los sancionadores, elección de la regulación autonómica aplicable en casos de ámbito supraautonómico, etc. Basta aquí poner de manifiesto que la LGUM no aporta a este respecto verdaderas soluciones que se puedan mantener y que, en realidad, incluso, a este respecto no contribuye lo más mínimo a reforzar la unidad de mercado sino a potenciar sus peligros alzando barrearas artificiosas a las competencias de supervisión de las autoridades de destino. Digamos, en su defensa, que quizás no era la Ley apropiada para acometer en su conjunto y correctamente todos estos intrincados problemas que seguramente podrían encontrar ahora una nueva y mejor oportunidad de solución en la futura Ley de Régimen Jurídico de las Administraciones Públicas que ahora se tramita.

\section{Juicio de constitucionalidad}

Hemos ido poniendo de relieve los inconvenientes de la solución que la LGUM construye bajo el manto de su principio de eficacia en todo el territorio nacional, los problemas que genera para la defensa de los intereses generales y las consecuencias que comporta para las competencias normativas autonómicas. También, finalmente, las desventajas que entraña su correlativa distribución territorial de las competencias de supervisión ¿Supone eso, además, que sea inconstitucional?

Contesta Fernández Farreres que "no faltan motivos para dudar de la constitucionalidad de este principio ... pues si la competencia para regular y controlar el acceso y ejercicio de la actividad económica ha quedado atribuida ... a las Comunidades Autónomas, implícitamente se está reconociendo que estas regulaciones podrán ser divergentes y, por tanto, desiguales los requisitos y exigencias requeridos para su desarrollo"37. Pero, en realidad para ser del todo exactos, la LGUM no impide que las Comunidades Autónomas sigan aprobando esas normas ni que sean divergentes ni que establezcan exigencias desiguales. Sólo merma su efectividad en tanto que las hace inoponibles a los operadores localizados en otra Comunidad. Esto no es del todo diferente de lo que impone el Derecho Europeo que, sin restringir las competencias de los Estados miembros para aprobar su propia regulación, también hace inoponibles muchas normas nacionales frente a los operadores y productos extranjeros. La diferencia estriba, como hemos visto, en que el Derecho de la Unión admite muchos más matices y excepciones que la LGUM y acaso lo que pueda considerarse inconstitucional es que esta Ley no reconozca ninguna posibilidad similar a las Comunidades Autónomas.

${ }^{37}$ G. FERNÁNDEZ FARRERES, “Unidad de mercado y libertades...”, cit., p. 139. 
El mismo Fernández Farreres apunta, siguiendo en parte ideas del Dictamen del Consejo de Garantías Estatutarias de Cataluña, otra objeción en contra de la eficacia extraterritorial de las actuaciones autonómicas: sería contraria a la regla general consagrada en los distintos Estatutos de la territorialidad de las competencias autonómicas y una excepción a esa regla general "sólo podría admitirse, a lo sumo, si la normativa habilitante fuese única", o sea, si fuese estatal, o "en otro caso, si el contenido de la pluralidad de normas autonómicas fuese idéntico"38. Pero generalmente se ha entendido que la territorialidad de las competencias autonómicas es un principio que admite variadas matizaciones y hasta frontales excepciones. Incluso los nuevos Estatutos han tratado de reflejarlo plasmando algunas ideas formuladas por el TC. Así, por ejemplo, puede verse en el Estatuto de Andalucía. Su art. 7 establece que las leyes y normas de las instituciones de Andalucía "tendrán eficacia en su territorio", pero añade: "Podrán tener eficacia extraterritorial cuando se deduzca de su naturaleza y en el marco del ordenamiento constitucional". Y el art. 43.1 del mismo Estatuto dice que "el ejercicio de las competencias autonómicas desplegará su eficacia en el territorio de Andalucía" pero señala como excepciones "los supuestos a que hace referencia expresamente el presente Estatuto y otras disposiciones legales del Estado que establecen la eficacia jurídica extraterritorial de las disposiciones y los actos de la Junta de Andalucía". Se admite, pues, que el mismo Estado prevea supuesto de extraterritorialidad. Y podrá hacerlo al ejercer cualesquiera de sus competencias normativas, inclusive las del art. 149.1.1 $1^{\mathrm{a}}$ y $13^{\mathrm{a}}$ CE. También podrá hacerlo, creo, en virtud del art. 149.1.8 $8^{\mathrm{C} E}$ que se refiere a "las reglas relativas a la aplicación y eficacia de las normas jurídicas" y a las "normas para resolver los conflictos de leyes". Entonces lo que hay que resolver es si este caso de la eficacia en todo el territorio nacional consagrado por la LGUM se puede amparar en alguno de esos títulos. Y si se admitiese tal cobertura competencial, la inconstitucionalidad habría que buscarla en las concretas reglas que ha establecido respecto a la aplicación y eficacia de las regulaciones autonómicas, así como en la elección de los puntos de conexión que ha elegido, inconstitucionalidad que no resulta fácil de argumentar y que tendría que basarse en la irrazonabilidad de esos puntos de conexión. Incluso cabría sostener que lo que la LGUM establece no es propiamente un supuesto de extraterritorialidad de normas y actos. Cabría decir que, por ejemplo, no se trata de que las normas y actos de Extremadura tengan eficacia como tales en Baleares, sino de algo distinto, de una simple relevancia del ordenamiento extremeño para el balear. Expresándolo ya con carácter general, se trataría de que la LGUM ha consagrado a estos efectos una determinada relevancia de cada ordenamiento autonómico para el resto de los ordenamientos autonómicos, relevancia en cuya virtud, aunque cada ordenamiento autonómico regula

\footnotetext{
${ }^{38}$ Ibídem, pp. 140-141.
} 
una realidad producida dentro de sus límites geográficos, produce ciertas consecuencias fuera de ellos. Esto, en sí, no me parece contrario al principio de territorialidad ${ }^{39}$.

Decía al principio que la LGUM es una norma original e ingeniosa. Añado, incluso, que es difícil sustraerse al atractivo de su refinada ingeniería jurídica. Por eso mismo el enjuiciamiento de su constitucionalidad necesitará de una doctrina novedosa que afronte los problemas que plantea y que realmente no se pueden abordar del todo y fácilmente con la jurisprudencia constitucional ya existente. No procede que intentemos abordar aquí esa tarea. Pero lo que sí procede concluir es que el resultado final de la LGUM, aunque se entienda que formalmente no quita ninguna competencia a las Comunidades Autónomas ni vulnera un principio constitucional de territorialidad, sí que las hace incapaces de canalizar una política propia y efectiva en su territorio incluso en materias de su exclusiva competencia y que provoca un extraño fenómeno de competencia sin poder efectivo para ordenar la realidad social que le incumbe en las materias que el bloque de la constitucionalidad les confía. Lo cierto, en suma, es que este principio desaforado de eficacia nacional trastoca la concepción del Estado autonómico y que, unido a su no menos radical principio de necesidad, supone una verdadera mutación constitucional con la más que cuestionable premisa de un mercado nacional fragmentado.

${ }^{39}$ Vid. M. REBOLLO PUIG, "El Derecho propio de Andalucía y sus fuentes", en S. MUÑOZ MACHADO y M. REBOLLO PUIG (Dirs.), Comentarios al Estatuto de Autonomía para Andalucia, Civitas, Madrid, 2008, pp. 154 a 156. 